الإمام يعقوب بن إسحاق الحضرمي وجهوده في القراءات القرآنية (دراسة تحليلية)

\title{
Al-Emam Yagoob Bin Ishag Al-Hadrami and his Efforts in Quranic Readings (Analitical Study)
}

د. عبدالله اسحاق عبدالله سليمان- أستاذ القرآن والقراءات المشارك بكلية التربية - بجامعة أم درمان الإسلامية - الخرطوم - السودان absuliman1978@gmail.com : البريد الالكتروني:

كلاستشهاد بهذا المقال:-

عبداله اسحاق ـ (2022). الإمام يعقوب بن إسحاق الحضرمي وجهوده في القراءات القر آنية (در اسة تحليلية .(مجلة جامعة

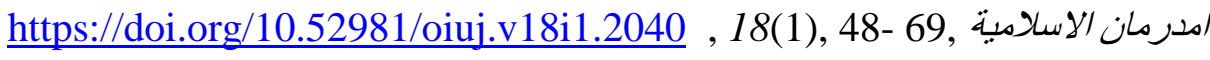

اتبع هذا البحث في دراسة هذا الموضوع المنهج الاستقرائي والوصفي، وذلك بتتبع سيرة الإمام يعقوب بن إسحاق الحضرمي وجهوده في القراءات القرآنية في المراجع المعتمدة، ودراستها دراسة علمية وفق ما هو متبع في البحوث العلمية. ولقد تم تقسم البحث إلى مقدمة وثلاثة مباحث، وخاتمة. ي المقدمة: تناول البحث أهمية الدراسة وأسباب اختيارها، ومشكلة الدراسة وأسئلتها، والدراسات التي سبقتها، وحدود الدراسة، ومنهج الدراسة. تناول في المبحث الأول: أسمه، وكنيته، ومولده، ووفاته، وشيوخه، وتلاميذه: وفي المبحث الثاني: قراءته، واجتماع الناس عليها، وشيوخه وتلاميذه من المحدثين، وحياته الاجتماعية، وأقوال العلماء فيه: وفي المبحث الثالث: أسانيده في القراءة، ومؤلفاته، ومنهجه، وأشهر من روى عنه: وفي الخاتمة: تناول البحث أهم النتائج والمصادر والمراجع. وفيما يلي: أهم النتائج التي تضمنته البحث:

$$
\begin{aligned}
& \text { 1. ـ كان يعقوب من أعلم أهل زمانه بالقرآن والنحو وغيرهما. } \\
& \text { 2. يعد يعقوب الحضرمي من القراء العشرة الذين تلقت الأمة قراءهم بالقبول. } \\
& \text { 3. أئتم بيعقوب في اختياره عامة البصريين بعد أبي عمرو بن العلاء البصري. } \\
& \text { 4. أشهر رواته في القراءة: محمد بن المتوكل المعروف برويس، وروح بن عبدالمؤمن. } \\
& \text { 5. نسبته إلى الحضارمة نسبة ولاء فقط ، لانسبة وطن أونسب. فهو بصري مولدا ووفاة. } \\
& \text { الكلمات المفتاحية: الامام يعقوب الحضرمي، حياته وجهوده في القراءات القرانية. }
\end{aligned}
$$




\begin{abstract}
:
This research used in studying this topic the inductive and descriptive methods to tracing the biography of Imam Yacoub bin Ishaq Al-Hadrami and his scholarly efforts in the Qur'anic readings (Qir $\bar{a}$ 'at $)$ as cited in the literature, and scientifically studying such efforts according to what is followed in scientific research. The research is divided into three: introduction followed by three chapters and a conclusion. Introduction contains the significance of the research, the rationale behind the selection of its subject, the problem of the research, its questions and limitations and the previous studies. In chapter one, the research dealt with the name of Imam Yacoub bin Ishaq Al-Hadrami, his nickname, birth, death, his students and Sheikhs. In chapter two, the research dealt with his Qur'anic reading and people's consensus on it, and his contemporary students and Sheikhs. It also tackled his social life and other scholars' opinions about his efforts. Chapter three contains the Assaneed (supporting evidences) of al-Imam Yacoub al-Hadrami to Qur'anic reading, his approach and books, and the popular scholars who have narrated about his efforts. In the conclusion, the research presented the most important findings and bibliographies.
\end{abstract}

The following are the most important findings

1. Yagoub al-Hadrami was one of the most knowledgeable scholars of the Qur'anic readings (Qirā'āt), Arabic grammar, and other related subjects.

2. Yaqoub al-Hadrami is counted as one of the ten readers who have received the nation's acceptance.

3 - Yaqoub al-Hadrami was as a guide in the selection of Basri laymen after Abu Amr Ibn Al-Ala Al Basri.

4. The most popular scholarly narrators of his Qur'anic readings (Qirā'āt) are Muhammad ibn alMutawakil who is known as 'Riweis' and Rouh Ibn 'Abd al-Mu'min.

5. The parentage of al-Imam Yaqoub to al-Hadramah is only because of his loyalty not a blood relationship, but he was born and died Basra in Iraq.

Keywords: a-l Imam Yaqoub Al-Hadrami, his life, and efforts in the Quranic Qur'anic readings (Qirā'āt)

$$
\begin{aligned}
& \text { المقدمة: } \\
& \text { الحمد لله الذي علم القرآن، وزين الإنسان بنطق اللسان، فطوبى لمن يتلو كتاب الله حق تلاوته، ويواظب آناء الليل وأطراف النهار على } \\
& \text { دراسته، وهو كلام الله تعالى الذي أنزله على عبده ورسوله المصطفى محمد النبي الأمي العربي المختار المرتضى- صلّى الله عليه وسلم } \\
& \text { وعلى آله المكرمين-، ورضي الله عن أصحابه أجمعين، وسلم تسليما كثيرا. }
\end{aligned}
$$


أمابعد: فإن علم القراءات من أَجَلِّ العلوم قدرًا، وأشرفها منزلة، وأرفعها مكانة، لتعلقه بكتاب الله عز وجل، وكلامه المبين- وقد سخر الله - عزوجل- أفذاذًا من علماء الأمة الإسلامية منذ فجر الإسلام لخدمة كتابه العزيز، فقاموا - بعون الله تعالى وتوفيق منه- خير قيام بدراسة كل ما يتعلق بالقرآن الكريع. فتخصص رجال من العباقرة في علوم القراءات، وأفنوا أعمارهم في خدمتها: تعليمًا وتأليفًا، وتمذيبًا وتلخيصًا. والمكتبات الإسلامية والعالمية مليئة بآثارهم العلمية، وهي خير شاهد على خدماقهم القرآنية الجليلة. ولذلك أحببت أن أكون ممن ينالمم ويشملهم شرف الانضمام إلى أهل القرآن، المتصفين به والعاملين بمقتضاه، فجاءت هذه الدراسة رغبة في ذلك ، وطمعاً فيما عند الله من الأجر والثواب.

\section{أولاً: أهمية موضوع الدراسة وأسباب اختياره :}

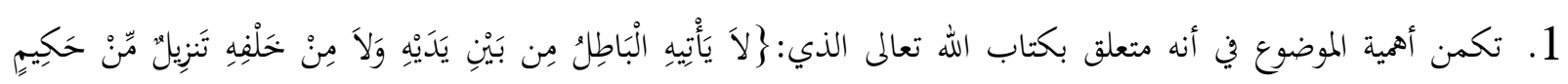

حَمِيد \{. سورة فصلت ، الآية:(42).

2. مكانة الإمام يعقوب بن إسحاق الحضرمي بين القراء كبيرة ، لأنه كان أقرأ القراء، وكان أعلمهم بالحروف، والاختلاف في القرآن، وتعليله، ومذاهب أهل النحو في القرآن، وأروى الناس لحروف القرآن وحديث الفقهاء.

ثانياً: مشكلة الدراسة:

يعد الإمام يعقوب الحضرمي من أئمة البصرة ، وكان من أعلم الناس بالقراءات والنحو، وتعد قراءته من القراءات السبع التي

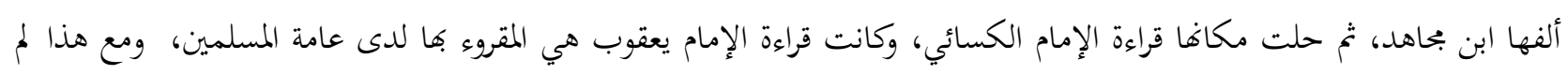
أقف على مفردة مستقلة عن ترجمته وجهوده في القراءات القرآنية، لكنني وقفت على كثير من الكتب المفردة في قراءته مثل: مفردة يعقوب لابن فحام الصقلي والداني وغيرها. ويتجلى مذهبه في النحو من خلال مذهبه في القراءة ، وكان ميالا في مذهبه إلى التسهيل، والإدغام، والوقف بالسكت، وضم هاء كل ضمير جمع مذكر. و وقد أشكل نسبته إلى الحضرمي على كثير من الناس، حتى ظن بعضهم أنه منسوب إلى حضرموت، ولعل السبب يرجع في اشتهاره ب( يعقوب الحضرمي)، ولكن القارئ في ترجمته يجده أنه لم يدخل بلاد اليمن قط، ومن باب أولى عدم دخوله حضرموت، وإنما نسب إلى الحضرمي ولاء، فهو بصري مولدا ووفاة. ومن خلال ماسبق تبرز

أسئلة الدراسة الآتية:

$$
\begin{aligned}
& \text { 1. من هو الإمام يعقوب بن إسحاق الحضرمي؟ } \\
& \text { 2. من هم شيوخه وتلاميذه في القراءة والحديث؟ } \\
& \text { 3. ماذا قال فيه العلماء؟ } \\
& \text { 4. ماسنده في القراءة؟ }
\end{aligned}
$$

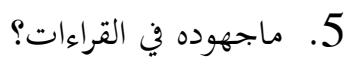




$$
\text { 7. } 6 \text { ما منهجه في القراءة؟؟ هو أشهر من روى عنه؟ }
$$

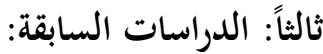

نقف على قراءة يعقوب في الكتب القديمة المؤلفة في القراءات الثمان، والقراءات العشر، والقراءات الأربعة عشر. ومن العلماء

من أفرد قراءة يعقوب في كتب مستقلة، ومن هؤلاء: 1. - أبوعمرو الداني، المتوف سنة:444هـ.

2. 2 أبو علي الأهوازي، المتوف سنة:446هـ.

3. محمد بن شريح الرعيني، المتوفى سنة:476هـ.

4. - 5 ابن فحام الصقلي، المتوفي سنة:516هـ.

5. شعيب بن عيسى الأشجعي، المتوف بعد سنة:530هـ.

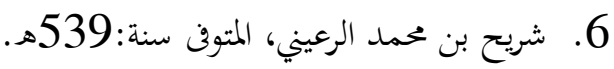

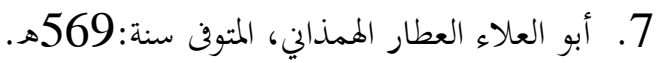

8. عبدالباري بن عبدالرمن الصعيدي، المتوفن سنة:650هـ.

9. أحمد بن موسى البطرين، المتوف قبل سنة:700هـ.

10. عبدالله بن محمد الواسطي، المتوف سنة:722هـ.

11. أبوحيان الأندلسي، المتوف سنة:745هـ.

12. محد بن أممد الورغمي التونسي، المتوف سنة:803هـ.

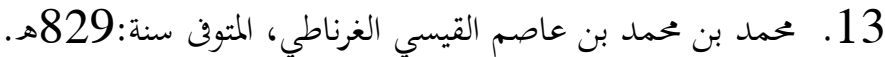

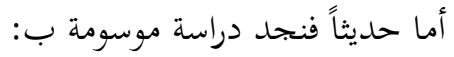

1 1. حياة القلوب في قراءة الإمام الحضرمي يعقوب، لخمد نبهان بن حسين المصري.

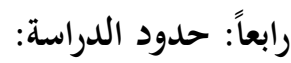

الإمام يعقوب بن إسحاق الحضرمي وجهوده في القراءات القرآنية

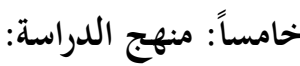

أتبع الباحث لدراسة هذا الموضوع المنهج الاستقرائي والوصفي؛ وذلك بتتبع واستخراج ترمة يعقوب بن إسحاق الحضرمي وجهوده في

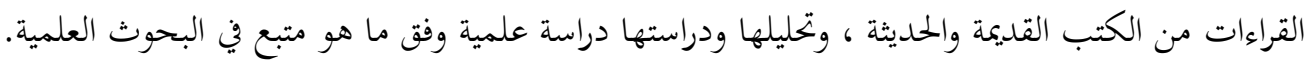

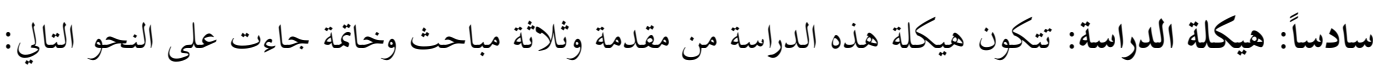
المبحث الأول: السمه، وكنيته ، ومولده، ووفاته، وشيوخه، وتلاميذه في القراءة: 
المبحث الثاني: قراءته ، واجتماع الناس عليها، وشيوخه وتلاميذه من المحدثين، وحياته الاجتماعية ، وأقوال العلماء فيه:

المبحث الثالث: أسانيده في القراءة، ومؤلفاته، ومنهجه ، وأشهر من روى عنه:

الخاتمة والنتائج والمصادر والمراجع.

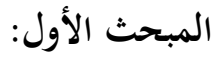 \\ اسمه، وكنيته ، ومولده، ووفاته، وشيوخه، وتلاميذه في القراءة :}

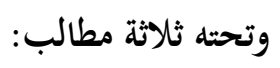

المطلب الأول: اسمه ، وكنيته ، ومولده، ووفاته:

الإمام البمود الحافظ ، مقرئ البصرة في عصره، مولى الحضرميين، النحوي ، أحد الأعلام، من أهل بيت العلم والفقه، وأحد القراء

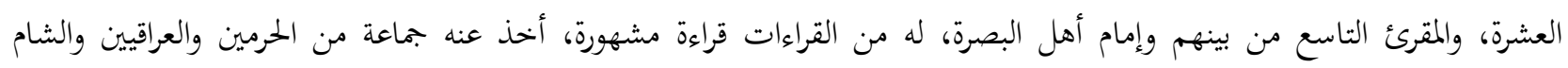

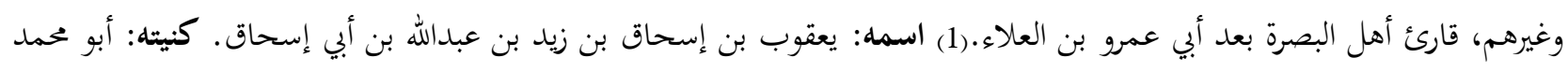

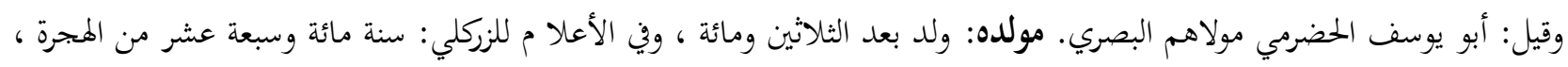

الموافق:(235 م) كان من الحضرميين من أهل البصرة ، يقال: إنه من موالي العلا الحضرمي.

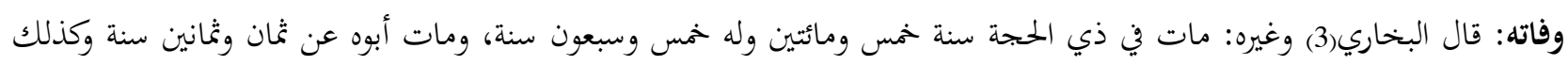

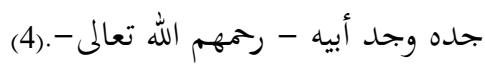
المطلب الثاني: شيوخه في القراءة: روى عن:

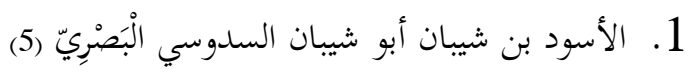

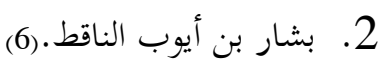
3. ماد بن سلمة بنِ دِيْنَارِ البَصْرِيُّ(7)

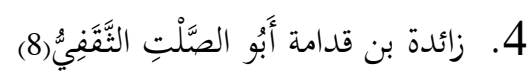
5. وسمع من جده زيد بن عبدالله بن أبي إسحاق. 6. أبي عوانة الوَضَّاحُ بنُ عَبْدِ اللهِ الوَاسِطِيُّ الوضاح(10) أخذ القراءة عرضا: عن:

1. أبي المنذر سلام بن سليمان الطويل (11)

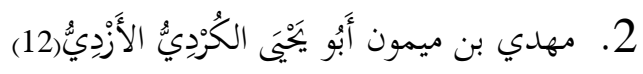
3. أبي الأشهب جَعْفَرُ بنُ حَيَّانَ العطاردي(13) وسمع حروفا عن: 1. شهاب بن شرنفة المحاشعي البصري(14) 


$$
\begin{aligned}
& \text { 2. مسلمة بن محارب بن دثار السدوسي الكوفي(15) } \\
& \text { 3. عصمة بن عروة أبو بنيح الفقيمي البصري (16) } \\
& \text { 4. يونس بن عبيد بنِ دِيْنَارٍ العَبْدِيُّ(17) } \\
& \text { 5. وروى عن سلام بن سليمان الطويل أبو المنذر المزني(18) حرف أبي عمرو بالإدغام. }
\end{aligned}
$$

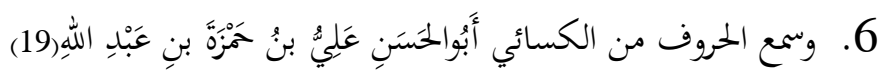

$$
\begin{aligned}
& \text { 7. . محمد بن زريق الكوي عن عاصم(20) } \\
& \text { 8. أبي عقيل الدورقي البصري(21) } \\
& \text { 9. هارون بن موسى أبو عبد الله الأعور، العتكي البصري الأزدي(22) } \\
& \text { 10 } 10 \\
& \text { 11 } \\
& \text { 12. }
\end{aligned}
$$

وروى ابن المنادى (27): أنه قرأ على أبي عمرو، قال أبوعبد الله القصاع: وما ذلك بن بعيد؛ لأن أبا عمرو توفي وليعقوب سبع وثلاثون سنة. قال يعقوب: قرأت على سلام في سنة ونصف، وقرأت على شهاب بن شرنفة المجاشعي(28) في خمسة أيام، وقرأ شهاب على على

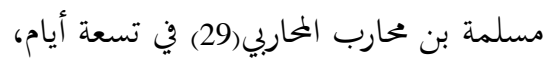
وقرأ مسلمة على أبي الأسود الدؤلي(30) على علي بن أبي طالب(31) رضي الله عنه. وقراءته على أبي الأشهب (32) عن أبي رجاء العطاردي(33) عن أبي موسى الأشعري(34) في غاية العلو.(35)

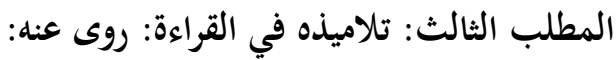

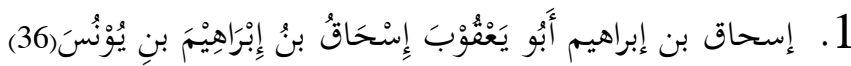

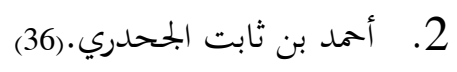
3. إبراهيم بن مرزوق بنِ دِيْنَارِ أَبُو إِسنحَاقَ البَصْرِيُّ(37)

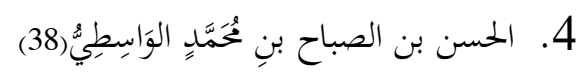

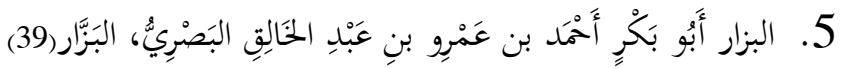

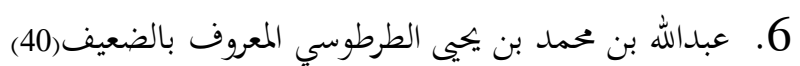

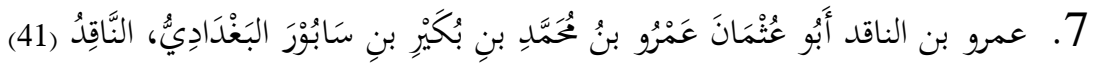

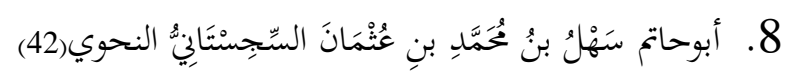
9. أبوالعباس القلوري هو أحمد بن عمرو المعصري (43)

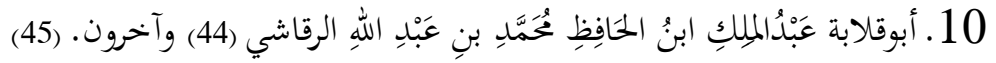

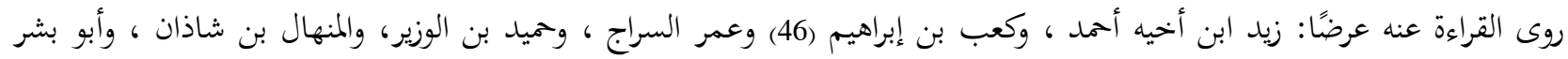

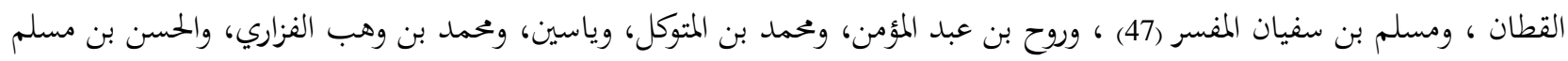




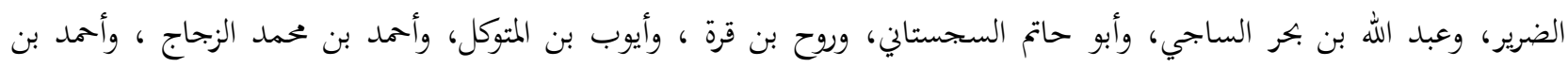

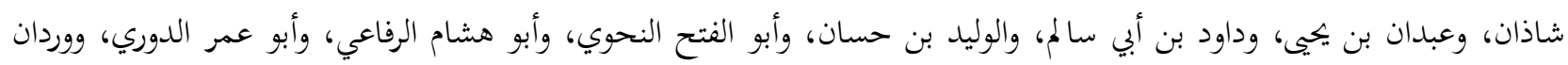

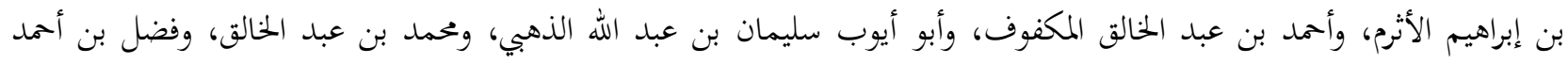

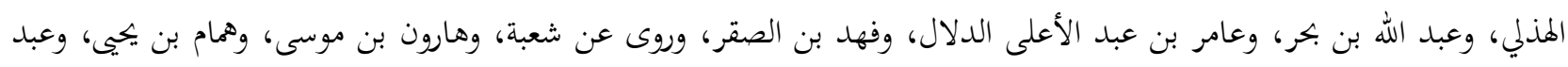

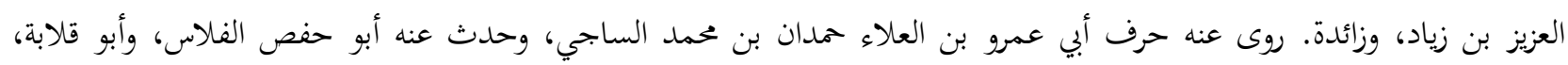

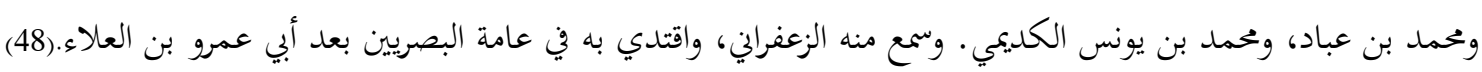

$$
\text { المبحث الثاني: }
$$

\section{قراءته واجتماع الناس عليها، وشيوخه وتلاميذه من المحدثين، وحياته الاجتماعية ، وأقوال العلماء فيه:

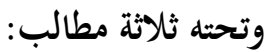

المطلب الأول: قراءته ، واجتماع الناس عليها:

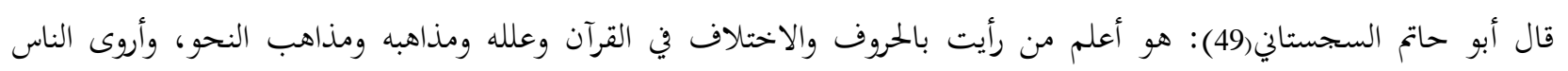

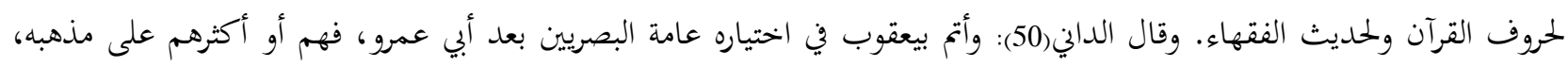

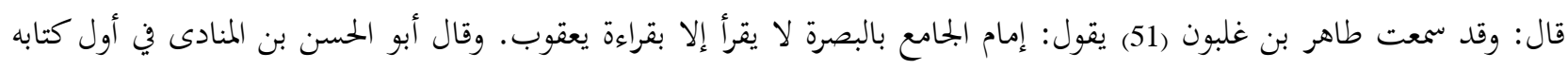

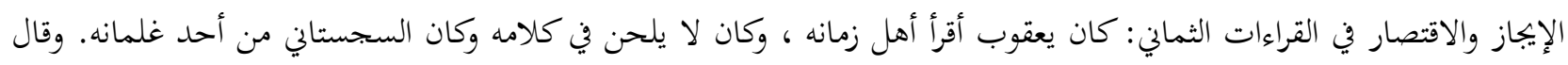

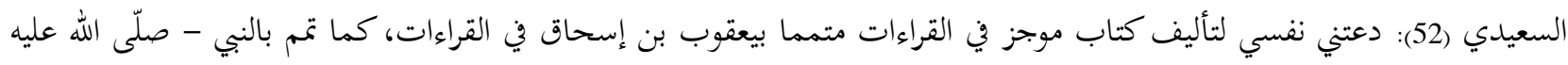

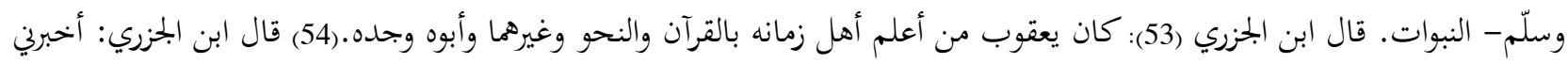

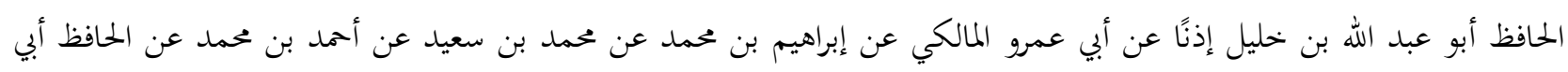

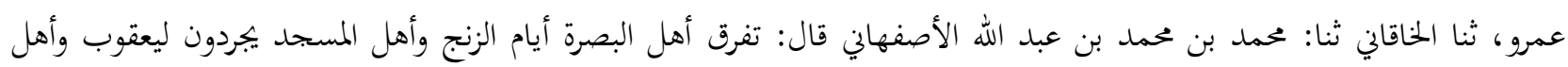

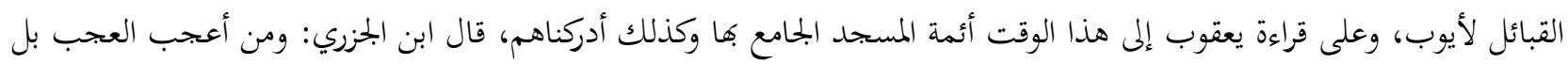

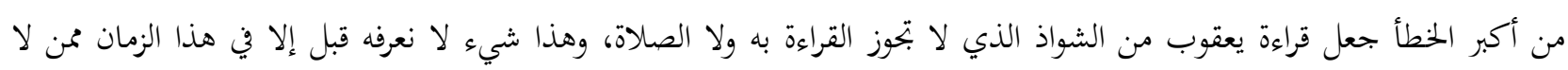

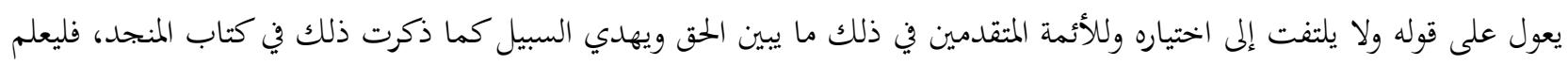

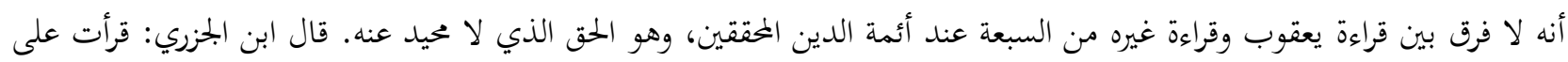

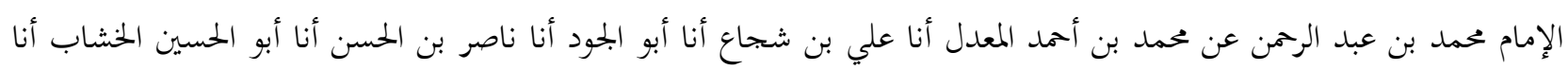

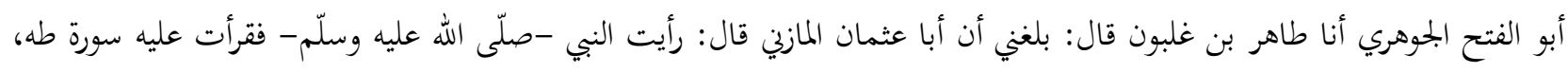

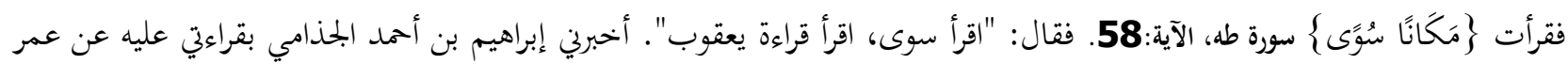

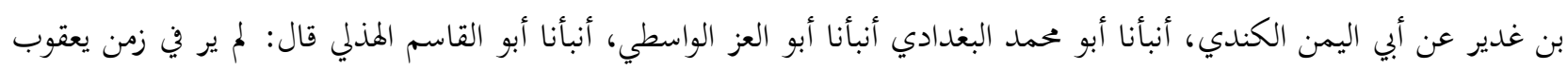

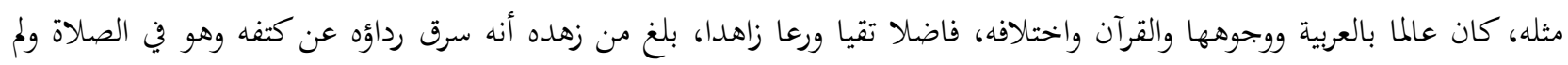

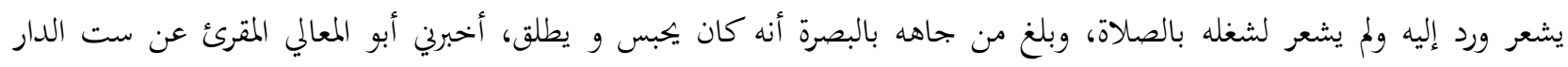

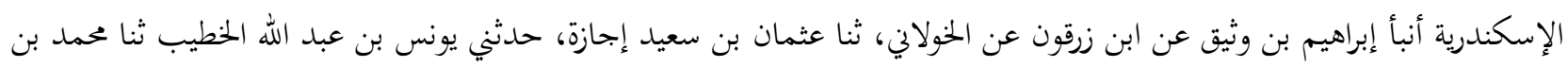

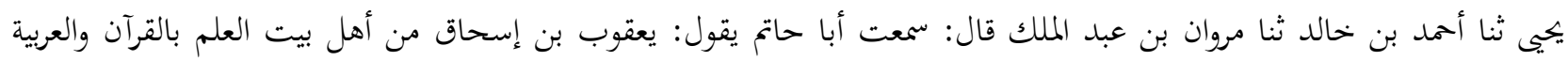


والرواية الكثيرة والحروف والفقه، وكان أقرأ القراء، وكان أعلم من أدركنا ورأينا بالحروف والاختلاف في القرآن وتعليله ومذاهب أهل النحو

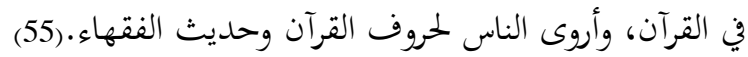

المطلب الثاني: شيوخه ، وتلاميذه من المحدثين:

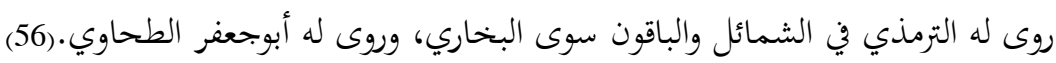

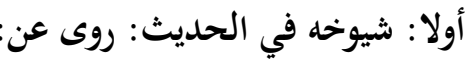
1. 1ائدة بن قدامة أبو الصلت الثقفي(57)

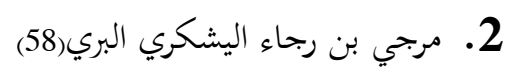

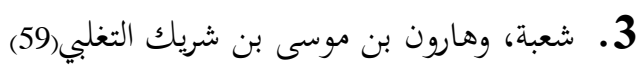
4. ثانيا:تلاميذه في الحديث: روى عنه:

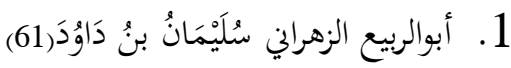

$$
\begin{aligned}
& \text { 2. عمرو بن الناقد. (62) }
\end{aligned}
$$

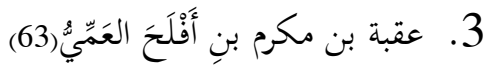

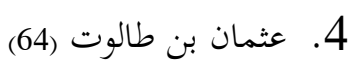

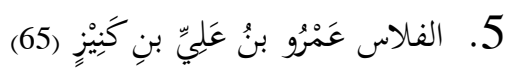

$$
\begin{aligned}
& \text { 6. أبوقلابة الرقاشي. (66) } \\
& \text { 7. إسحاق بن إبراهيم شاذان(67) } \\
& \text { 8. الكديمي(68) وخلق سواهم (69) }
\end{aligned}
$$

المطلب الثالث: حياته الإجتماعية ، وأقوال العلماء فيه:

أولا: حياته الاجتماعية:

هو من بيت علم بالعربية والأدب، وكان أخوه أحمد بن إسحاق الحضرمي أسن منه يكنى أبا إسحاق، وكان ثقة، مات بات بالبصرة في شهر

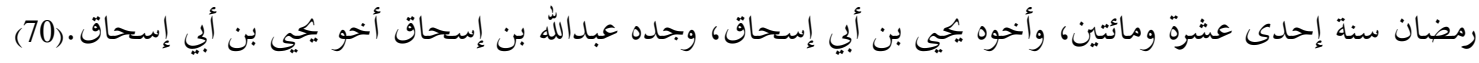

ثانيا: أقوال العلماء فيه:

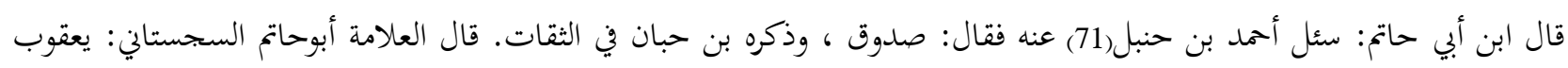

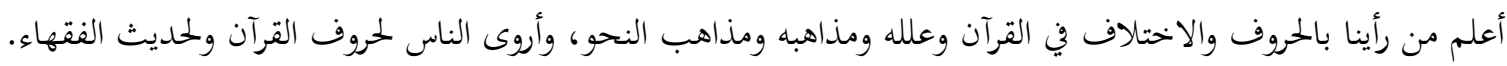

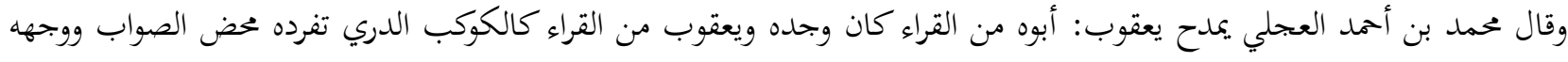
فمن مثله في وقته وإلى الحشر. قال الداني: وأئتم بيعقوب في اختياره عامة البصريين بعد أبي عمرو فهم أوأكثرهم على مذهبه

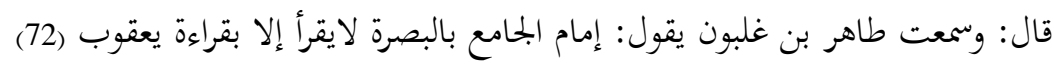


وقال الإمام علي بن جعفر السعيدي(73): كان يعقوب أقرأ أهل زمانه وكان لايلحن في كلامه ، وكان أبو حاتم السجستاني من بعض غلمانه (74). وقال أبوالحسن بن المنادى في أول كتابه الإيجاز والإقتصار في القراءات الثمان: كان يعقوب أقرأ أهل زمانه وكان لايلحن في كلامه ،

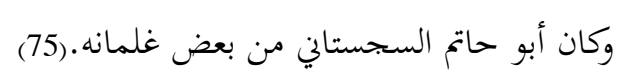
وقال السعيدي: دعتني نفسي لتأليف كتاب موجز في القراءات متمما بيعقوب بن إسحاق في إن القراءات كما تمم بالنبي - صلى الله عليه وسلم - النبوات. قلت: وكان يعقوب من أعلم أهل زمانه بالقرآن والنحو وغيره.(76)

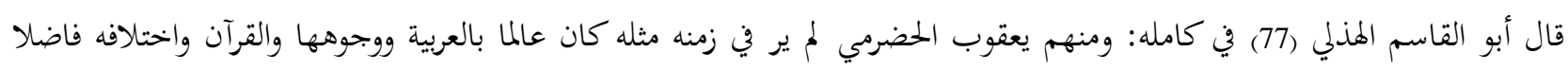

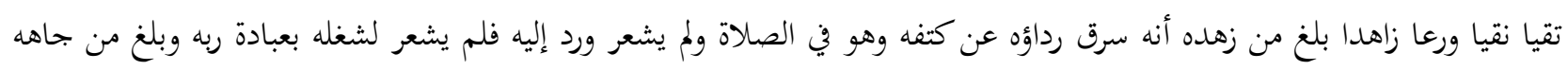
بالبصرة أنه كان يجبس ويطلق. (78)

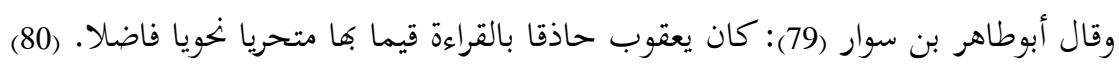

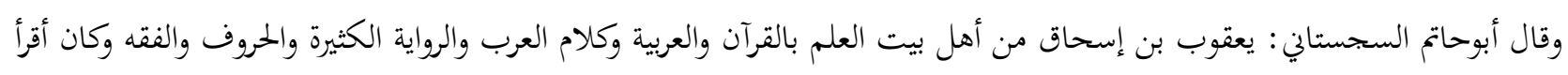

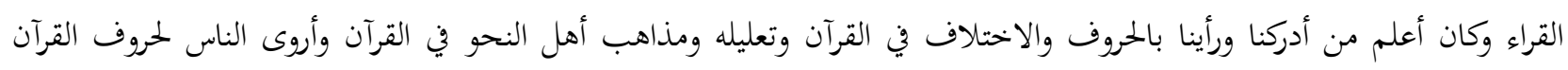
وحديث الفقهاء. (81)

المبحث الثالث:

أسانيده في القراءة، ومؤلفاته، ومنهجه ، وأشهر من روى عنه:

وتحته ثلاثة مطالب:

المطلب الأول:أسانيده في القراءة، ومؤلفاته أولا: أسانيده في القراءة:

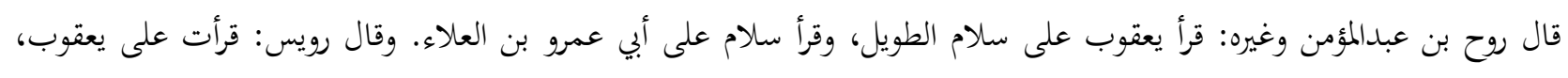

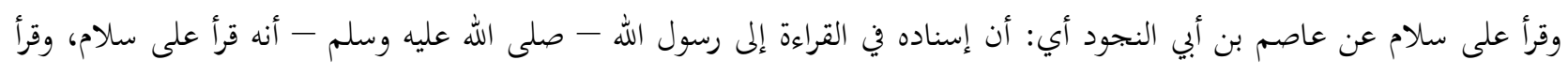

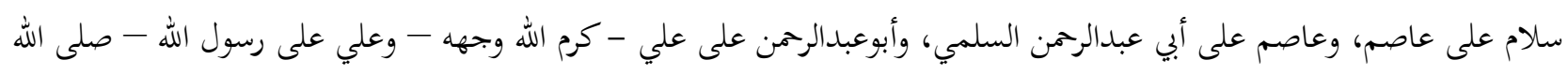
عليه وسلم. ثانيا:مؤلفاته: 1. له كتاب سماه الجامع ، قال الزبيدي: جمع فيه عامة اختلاف وجوه القرآن ونسب كل حرف إلى من قرأه. 2. 3. 32). المطلب الثاني: منهجه في القراءة: 1. قرأ يعقوب بالسكت بين السورتين بلا بسملة وهو الوجه المقدم في الأداء من الروايتين. 2. قرأ من رواية رويس لفظ ( الصِّراطَ ) كيف وقع في القرآن معرفاً أو منكراً بالسين، وقرأ روح بالصاد الخالصة موافقة لأصله. 3. قرأ بقصر المد المنفصل ، وتوسط المد المتصل بقدر أربع حركات. 
4. قرأ من رواية رويس بتسهيل ثاني الممزتين من كلمتين المتفقتين في الحركة، وقرأ روح بتحقيق الممزتين ، أما المختلفتان فيها فيقرأ بتغيير ثانيتهما كما يقرأ أبو عمرو.

5. قرأ من رواية رويس بتسهيل ثاني الممزتين من كلمة من غير إدخال، وقرأ روح بتحقيق الهمزتين من غير إدخال.

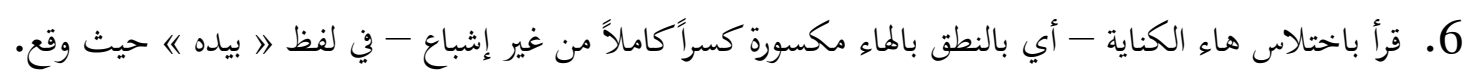

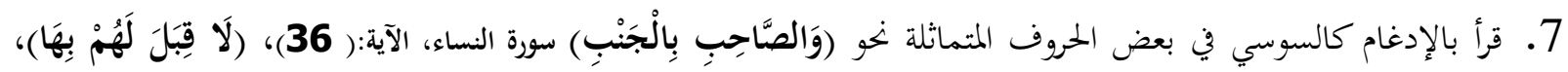

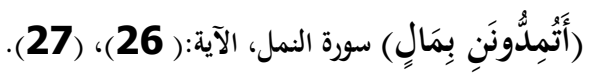

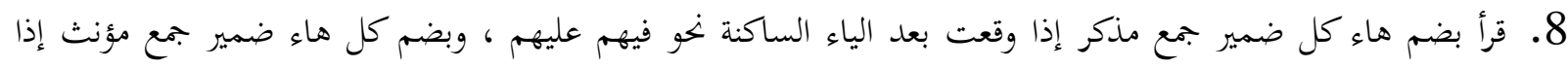

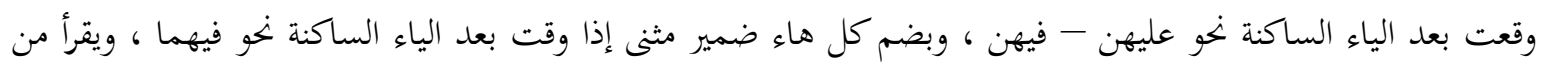

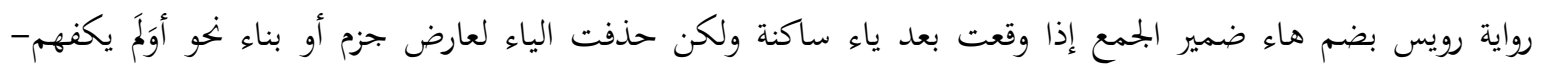
فاستفتهم. 9. يقف على هذه الألفاظ بماء السكت ( فيم - عم - مم - ملم - بم - وهو - وهي - عليهن - لَدَّ - إلىّ - يا أسفي -

$$
\begin{aligned}
& \text { يا حسرتي - تًَ ). } \\
& \text { 10. يسكن بعض ياءات الإضافة ، ويفتح بعضها. }
\end{aligned}
$$

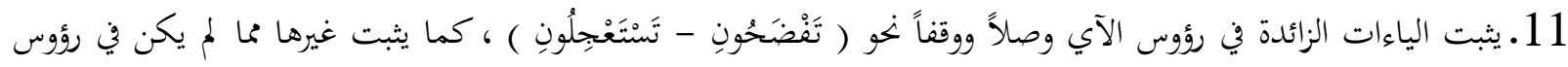
الآي.

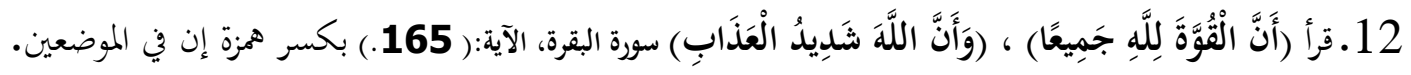

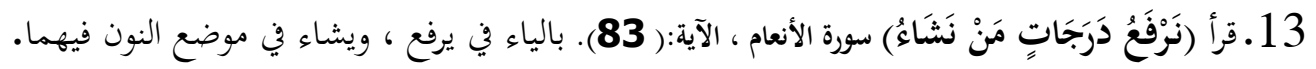

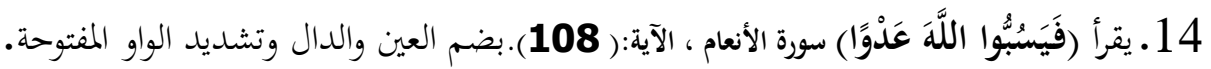

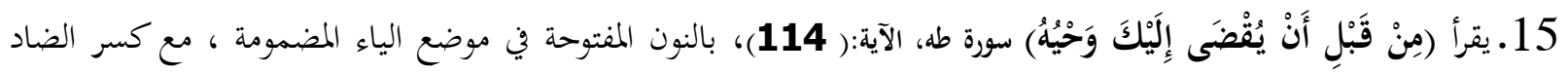
ونصب الياء في نقضي ، ونصب الياء في وحيه.

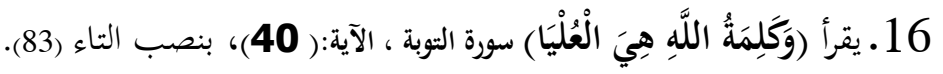
المطلب الثالث: أشهر من روى عنه: أولا: رويس المطاب إسمه: محمد بن المتوكل بن عبدالرمن ، أبوعبدالله اللؤلؤي البصري ، المعروف برويس، مقرئ حاذق، ضابط ، مشهور مولى بني هاشم بلمائ

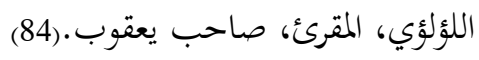
شيوخه: أخذ القراءة عرضا عن يعقوب الحضرمي. قال الداني: وهو من أحذق أصحابه. قال الأستاذ أبوعبدالله القصاع: كان يعني رويسا مشهورا جليلا. (85)

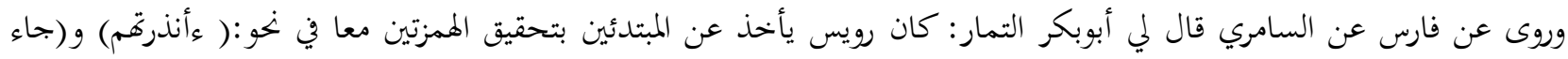

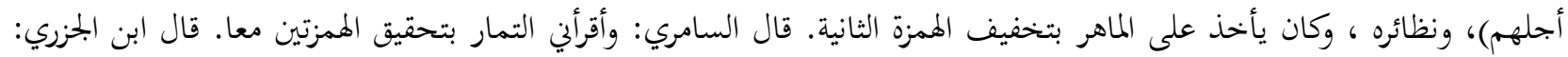


والتحقيق عن رويس في الهمزتين غير معروف فهو مما انفرد به السامري. قال الزهري: سألت أباحاتم عن رويس هل قرأ على يعقوب؟

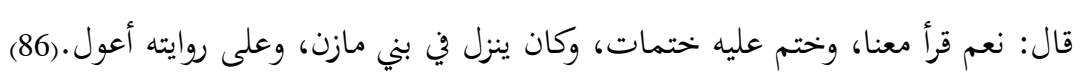

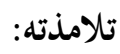

قرأ عليه محمد بن هارون التمار، وأبوعبدالله الزبيري الفقيه الشافعي.(87)

عدالثه الحديثية:

أسند عن الفضيل بن عياض وغيره ، وأخرج عنه أبوداود في سنه وغيره ، و واتفقوا على صدقه وثقته. (88)

كراماته:

قال: رأيت النبي - صلى الله عليه وسلم - في المنام فقلت: يارسول الله استغفر لي فقد حدثنا سفيان بن عيينة عن أبي الزهر عن جابر:

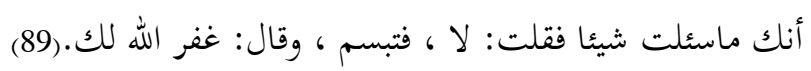
وفاته: توفى بالبصرة سنة ثمان وثلاثين ومائتين.(90)

ثانيا: روح

اسمه: روح بن عبد المؤمن، وقال الأهوازي: هو ابن عبدالمؤمن بن عبدة بن مسلم ، أبوالحسن الهذلي، مولاهم البصري النحوي، كذا

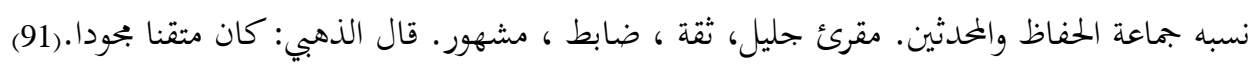

شيوخه:

عرض على يعقوب الحضرمي وهو من جلة أصحابه ، وروى الحرف عن أحمد بن موسى ، ومعذ بن معاذ ، وابنه عبيدالله بن معاذ ،

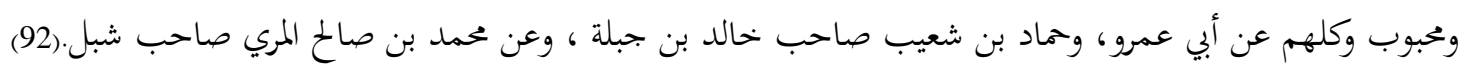

تلامذته:

عرض عليه الطيب بن الحسن بن حمدان القاضي، وأبوبكر بن محمد بن وهب الثقفي ، ومحمد بن الحسن بن زياد، وأحمد بن يزيد

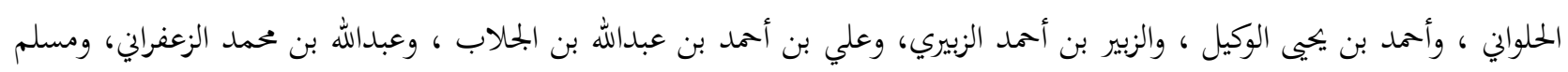

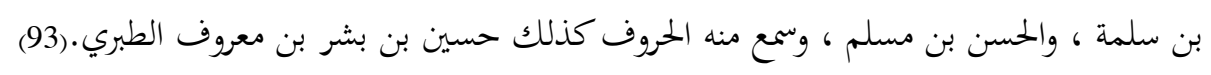
رواياته في الحديث:

روى عنه البخاري في صحيحه، قال عنه في تقريب التهذيب: صدوق من العاشرة ، وروى عن يزيد بن زريع ، وحماد بن زيد،

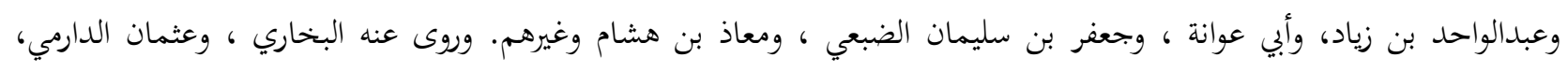

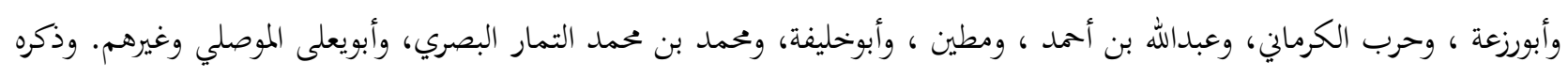

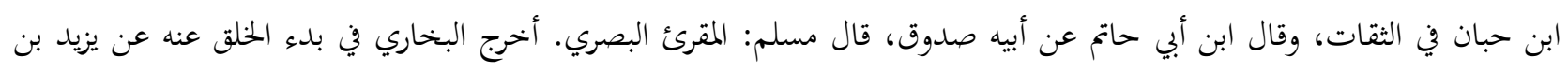

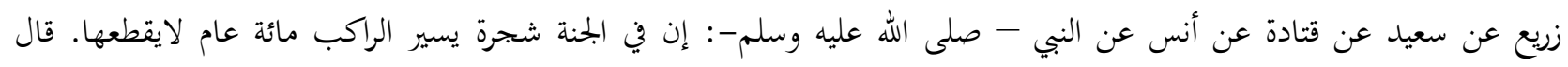

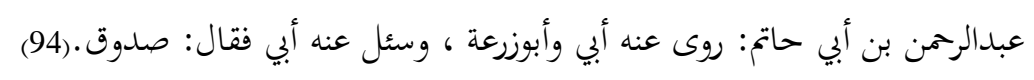

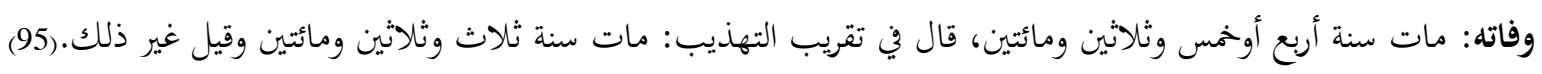


الخاتمة:

الحمد لله الذي وفقني وأعانني لإتمام هذا البحث ، وأساله تعالى دائماً العون في جميع أموري، وأصلي وأسلم على سيدنا ومولانا محمد صلّى الله عليه وسلم صفوة رسله، وعلى آله وصحبه الطيبين الطاهرين، وسلم تسليما كثيرا. ومن خلال سرد سيرة الإمام يعقوب بن إسحاق الحضرمي وجهوده في القراءات القرآنية: خلص الباحث من دراسته بالآتي:

$$
\begin{aligned}
& \text { 1. كان يعقوب من أعلم أهل زمانه بالقرآن والنحو والعربية وكلام العرب وغيرهما. } \\
& \text { 2. يعد يعقوب الحضرمي من القراء العشرة الذين تلقت الأمة قراءقم بالقبول. } \\
& \text { 3. أنتم بيعقوب في اختياره عامة البصريين بعد أبي عمرو بن العلاء البصري. } \\
& \text { 4. أشهروواته في القراءة: محمد بن المتوكل المعروف برويس، وروح بن عبدالمؤمن. }
\end{aligned}
$$

5. نسبته إلى الحضارمة نسبة ولاء فقط ، لانسبة وطن أونسب. فهو بصري مولدا ووفاة.

التوصيات:

أوصي الباحثين وطلاب العلم الاهتمام بدراسة سير القراء العشرة ورواتم وجهودهم في نشر القراءات القرآنية.

وصلى الله وسلم على نبينا محمد وعلى آله وصحبه وسلم

الهوامش:

(1) غاية النهاية في طبقات القراء لشمس الدين أبو الخير ابن الجزري، محمد بن محمد بن يوسف المتوف:(833هـ)، الطبعة: عني بنشره

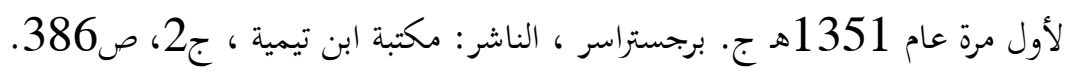

(2) مفردة يعقوب للعلامة: عبدالرحمن بن أبي بكر عتيق بن خلف المعروف بابن الفحام الصقلي المتوفف:(516هـ) ، الطبعة:

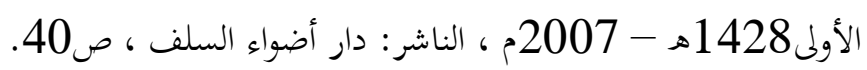

(3) أبو عبدالله البخاري محمد بن إسماعيل بن إبراهيم بن المغيرة بن بردزبة الجعفي ، ولد أبوعبدالله في شوال سنة أربع وتسعين ومائة.

انظر: سير أعلام النبلاء لشمس الدين أبو عبد الله محمد بن أحمد بن عثمان بن قَايْماز الذهبي:(المتوفى : 748هـ) المحقق : بحموعة من المققين بإشراف الشيخ شعيب الأرناؤوط ، الطبعة: الثالثة 1405 هـ - 1985 م ، الناشر: مؤسسة الرسالة ،

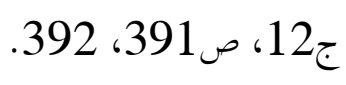

(4) غاية النهاية في طبقات القراء ، ج2، ص 389.

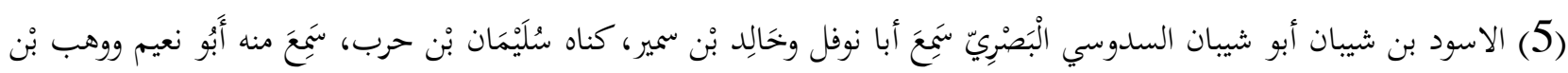

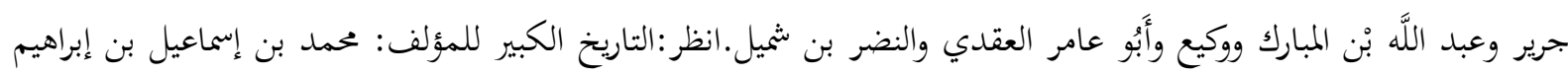
بن المغيرة البخاري، أبو عبد الله (المتوف: 256هـ) ، الطبعة: دائرة المعارف العثمانية، حيدر آباد - الدكن، طبع تحت مراقبة: 


$$
\text { (6) محمد عبد المعيد خان. ج1، ص446. }
$$

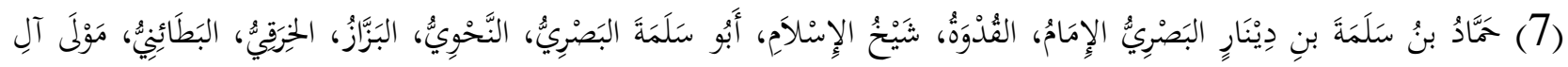

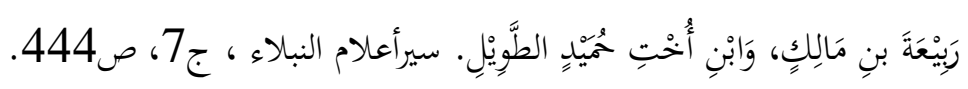

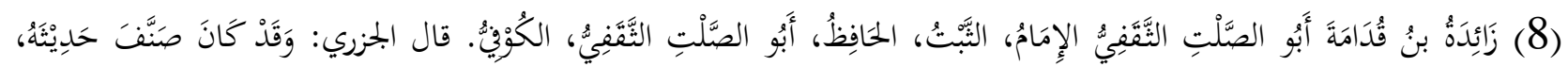

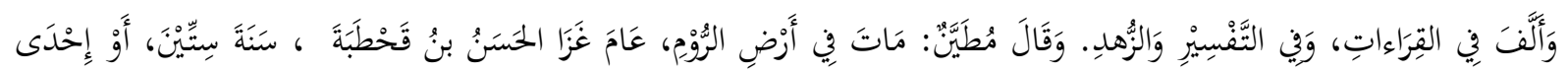

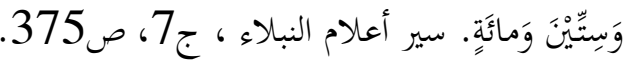

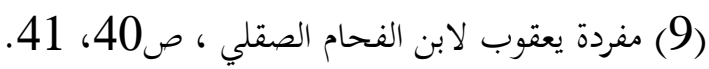

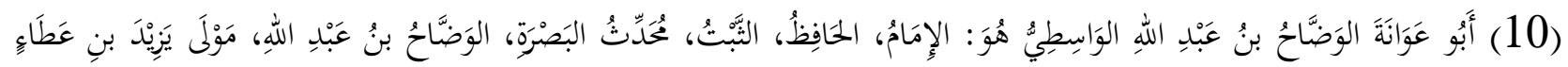

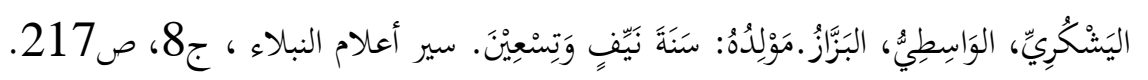

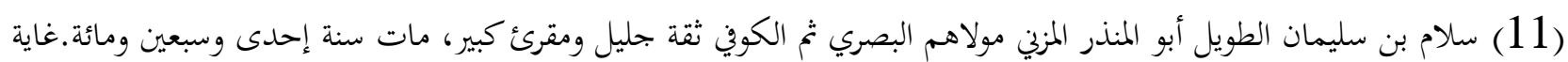

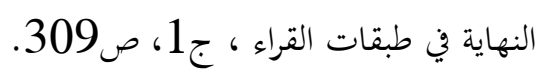

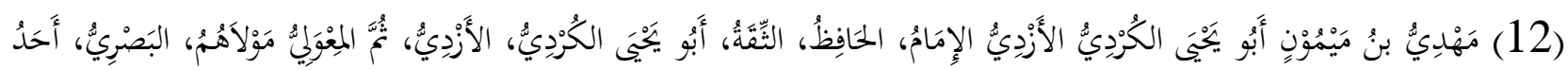

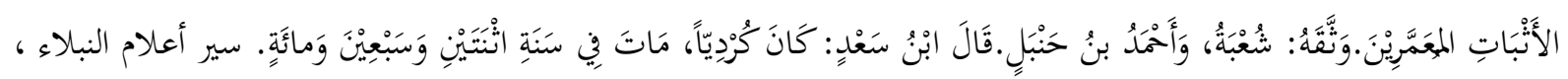

$$
\text { ج8 ، } 10
$$

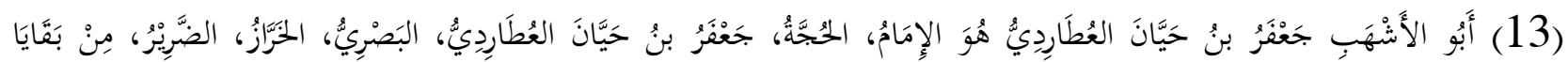

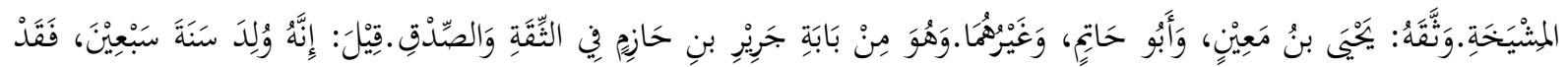

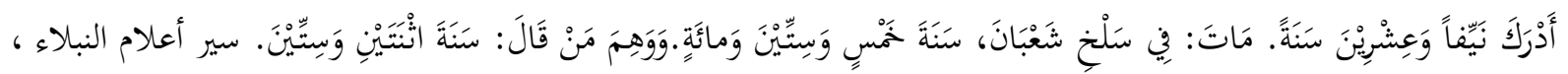

$$
\text { جان، ص286. }
$$

(14) شهاب بن شرنفة بضم الشين وسكون الراء وفتح النون وضمها البحاشعي البصري كان من جلة المقرئين بعد أبي عمرو مع الثقة

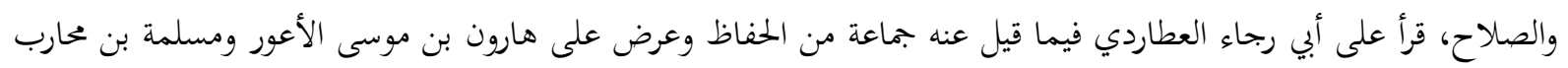

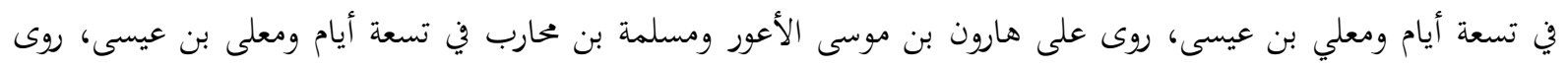

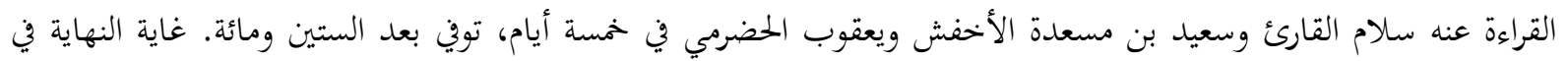

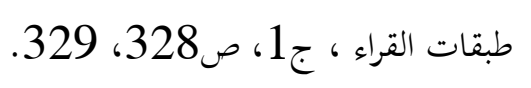

(15) مسلمة بن محارب بن دثار السدوسي الكوفي، عرض على أبيه، عرض عليه يعقوب الحضرمي. غاية النهاية في طبقات القراء ،

$$
\text { ج2، ص298. }
$$

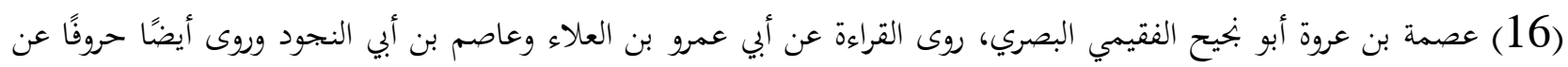

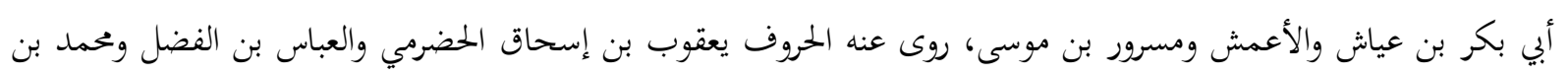


يجيى القطعي وإسماعيل بن عمارة، وهو المنفرد عن أبي بكر5 برواية مستطر بتشديد الراء لم يروه غيره. غاية النهاية في طبقات

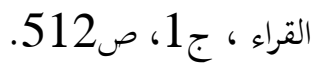

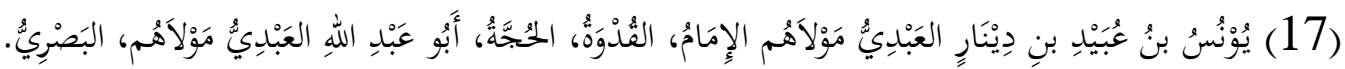

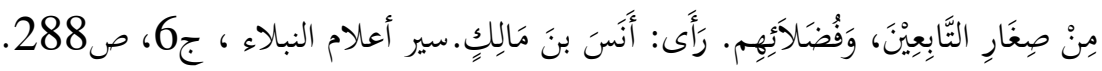
(18) سلام بن سليمان الطويل أبو المنذر المزني مولاهم البصري ثم الكوين ثقة جليل ومقرئ كبير، أخذ القراءة عرضا عن عاصم بن أبي

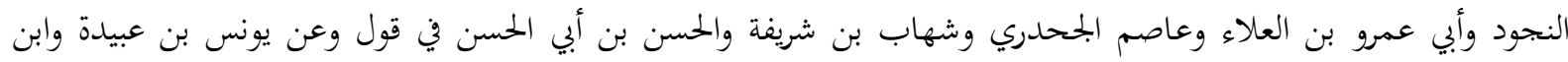

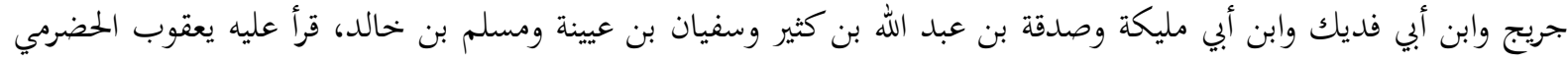

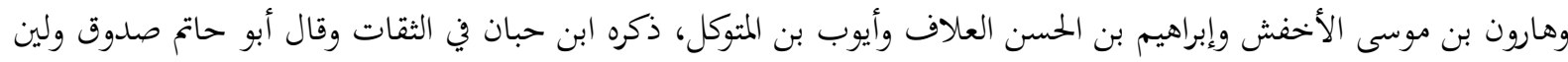

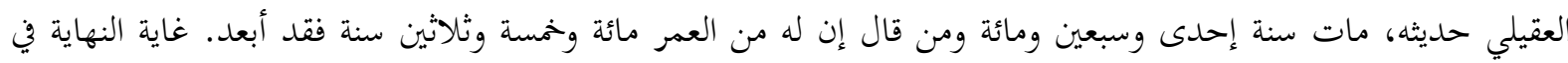

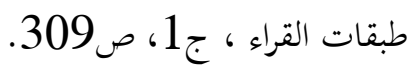

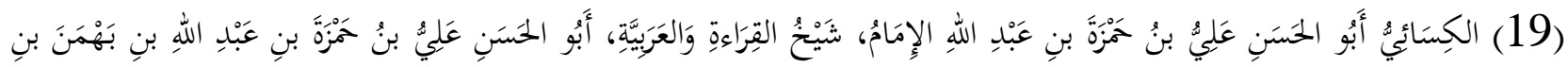

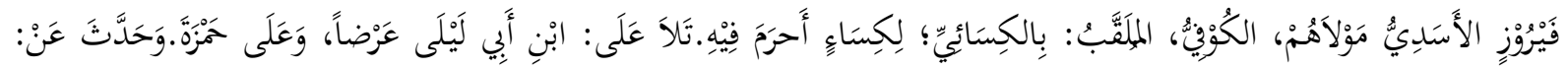

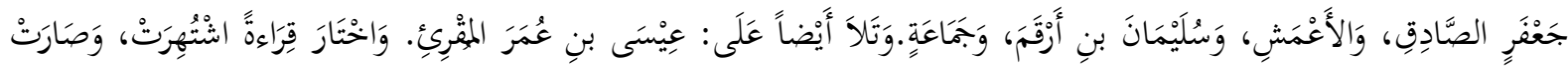

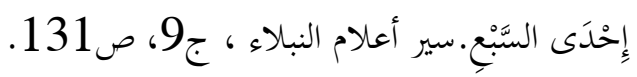

(20) محمد بن زريق أبو بكر، روى القراءة عن الكسائي وروى قراءة عاصم عن الحارث بن نبهان، رواها عنه جعفر بن موسى الهلالي،

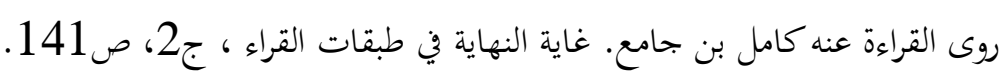

(21) بشير بن عقبة الناجي السامي ويقال الأزدي أبو عقيل الدورقي البصري. روى عن أبي المتوكل وأبي نضرة والحسن وابن سيرين

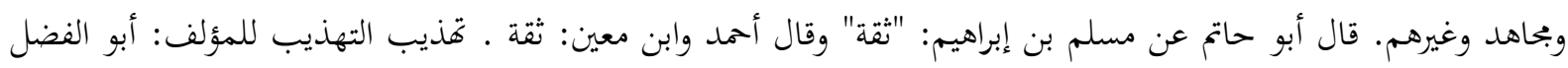
أحمد بن علي بن محمد بن أحمد بن حجر العسقلاني (المتوفن: 852هـ)، الناشر: مطبعة دائرة المعارف النظامية، الهند ، الطبعة:

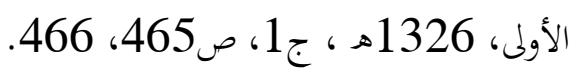

(22) هارون بن موسى أبو عبد الله الأعور، العتكي البصري الأزدي مولاهم، علامة صدوق نبيل له قراءة معروفة، روى القراءة عن

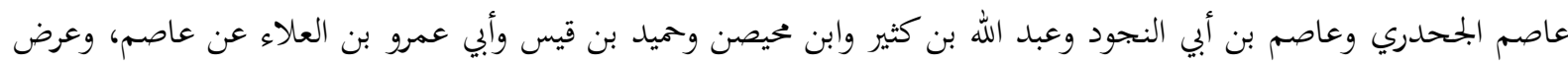

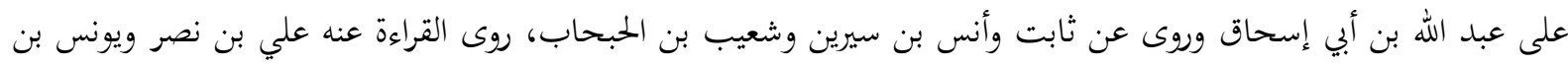

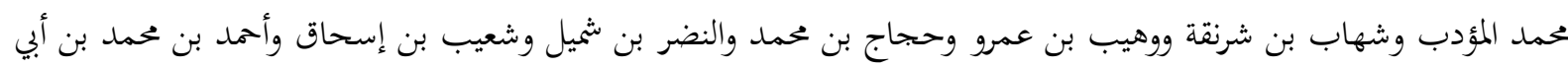

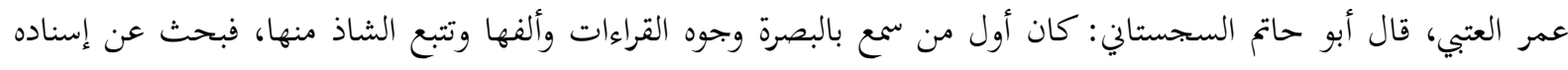
هارون بن موسى الأعور وكان من القّرّاء مات هارون فيما أحسب قبل المائتين. غاية النهاية في طبقات القراء ، ج2، ص348.

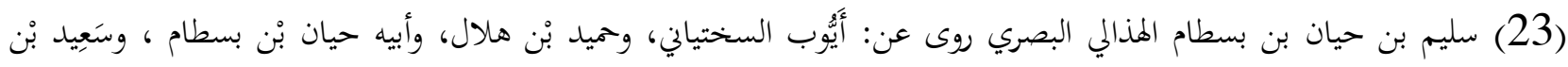

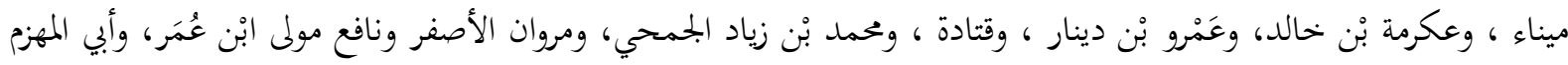

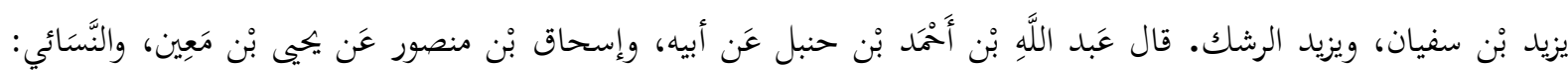


ثُقة.وَقَال أَبُو حاتم : ما بِهِ بأس.وذكره ابنُ حِبَّان في كتاب "الثقات". تحذيب الكمال في أسماء الرجال للمؤلف: يوسف بن عبد

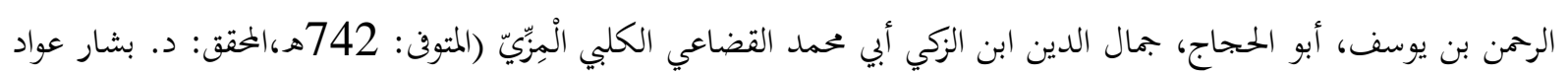

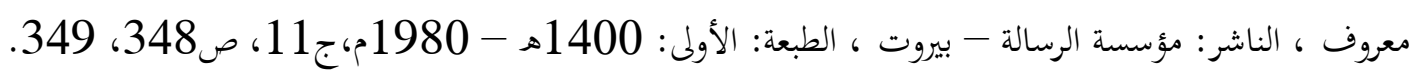

(24) سبق ترجمته في صعروف 7 (24)

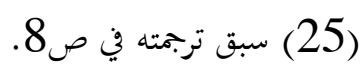

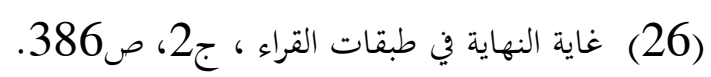

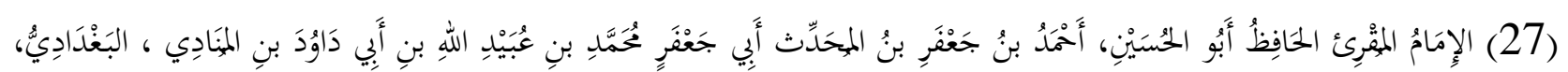

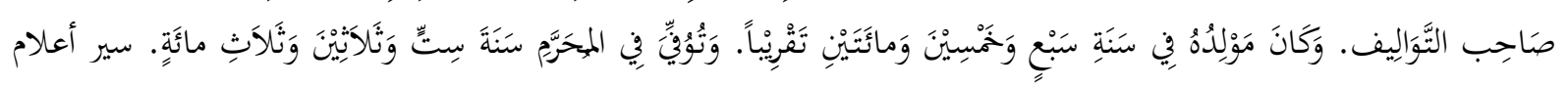

$$
\begin{aligned}
& \text { النبلاء ، ج15، ص362. } \\
& \text { (28) سبق ترجمته في ص8. } \\
& \text { (29) سبق ترجمته في ص9. }
\end{aligned}
$$

(30) أبو الأسود الدؤلي قاضي البصرة واسمه على الأصح: ظالم بن عمرو.قرأ على علي -رضي الله عنه، وكان من وجوه شيعبة، وروى

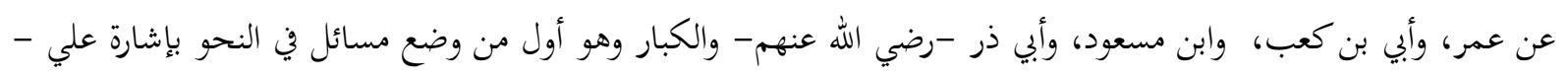

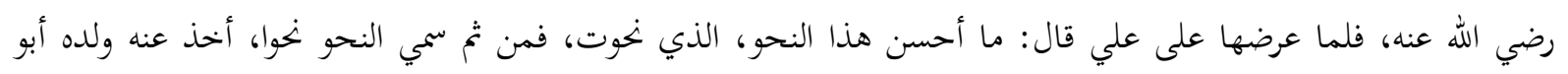

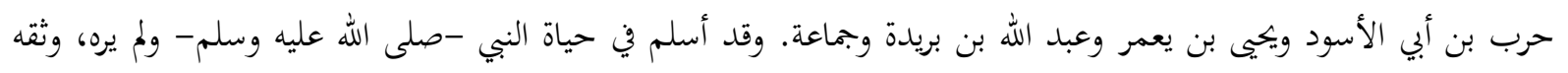

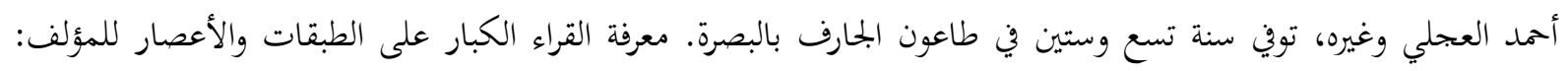

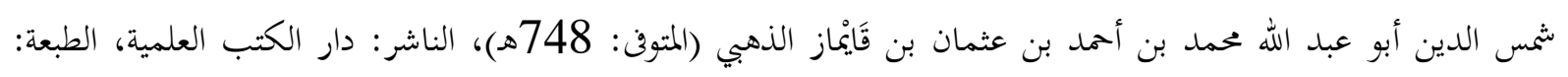
الأولى 1417 هـ- 1997م، صند31. (31) علي بن أبي طالب بن عبد المطلب بن هاشم بن عبد مناف بن قصي بن كلاب أمير المؤمنين أبو الحسن الهاشمي -رضي الله

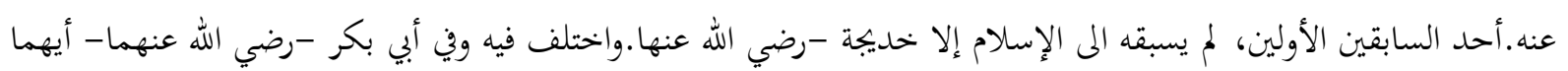

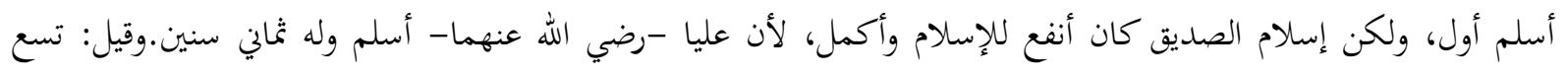
سنين.وقيل: ابن عشر سنين، وقيل ابن اثنتي عشرة سنة، وقيل ابن ثلاث عشرة، وقيل ابن خمس عشرة. معرفة القراء الكبار على إنى الطبقات والأعصار، ص11 11. (32) سبق ترجمته في ص 82 (2)

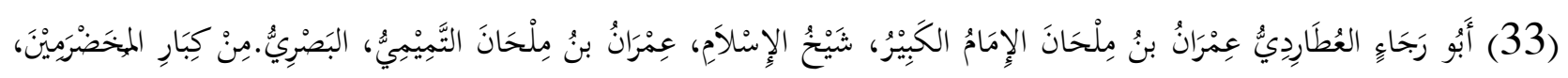

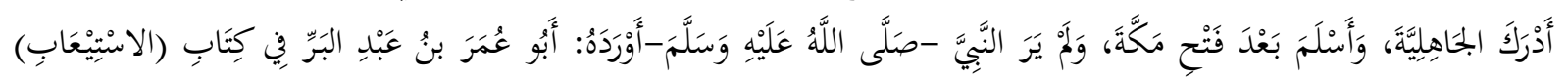

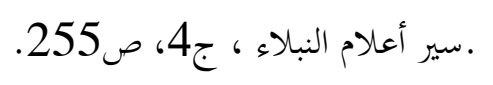

(34) أبو موسى الأشعري عبد الله بن قيس بن سليم بن حضار الأشعري اليماني -رضي الله عنه. هاجر إلى النبي - صلى الله عليه

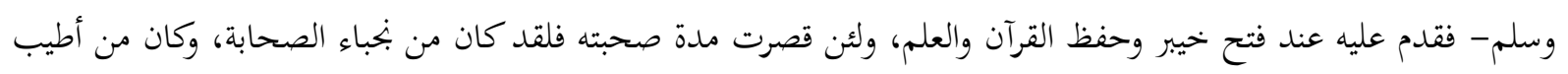


الناس صوتا، سمع النبي -صلى الله عليه وسلم- قراءته فقال: "لقد أوتي هذا مزمارا من مزامير آل داود" ، وقد استغفر له النبي -

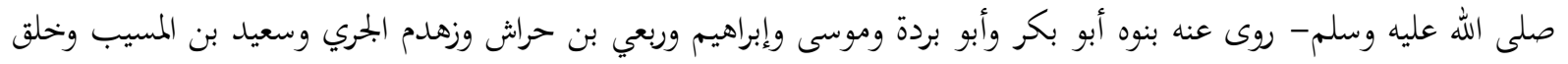

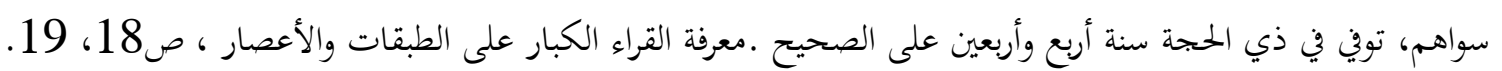
(35) غاية النهاية في طبقات القراء ، ج2، صوك3.

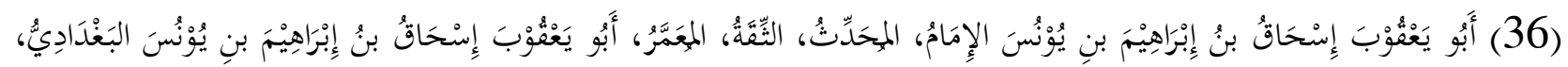

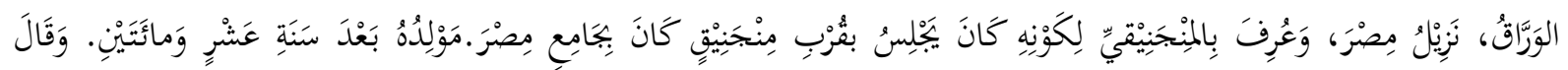

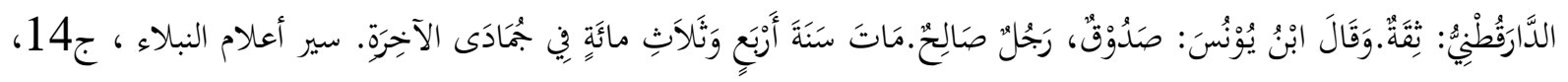

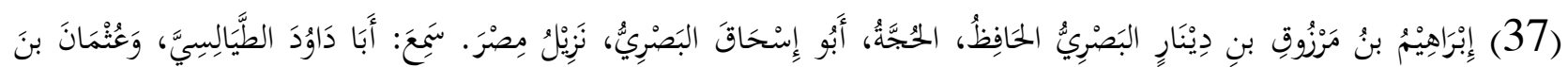

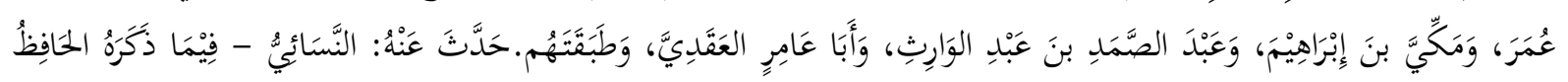

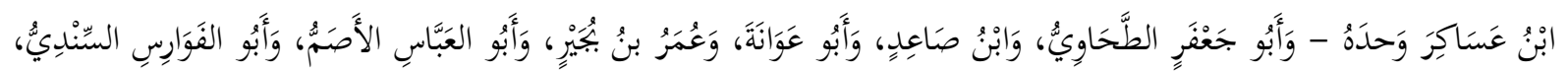

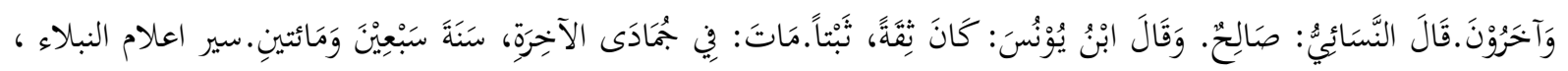

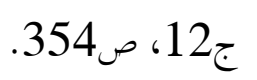

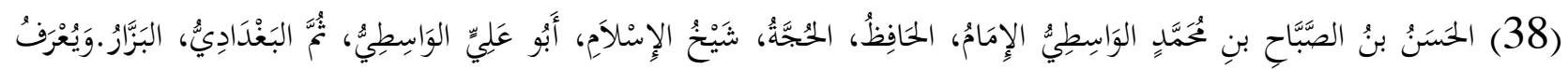

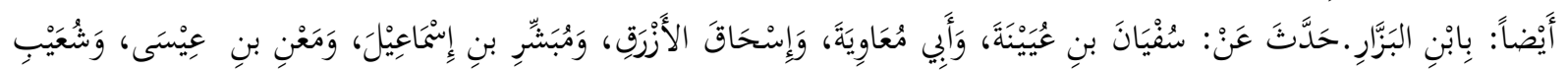

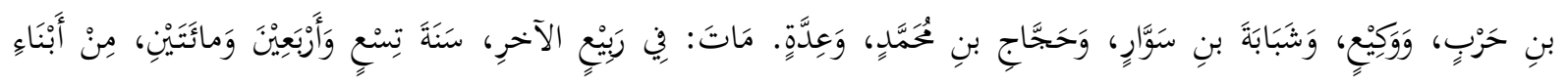

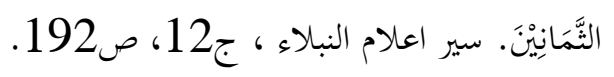

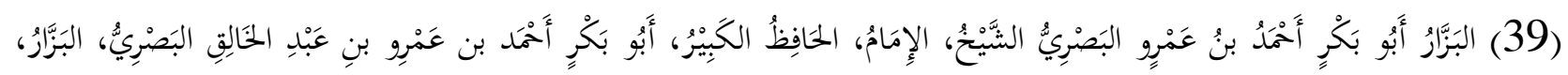

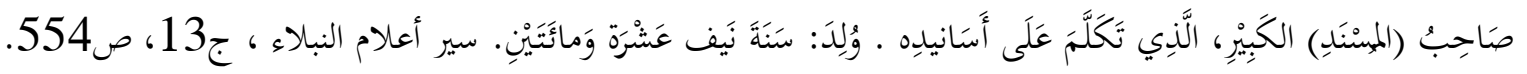
(40) عبد الله ابن محمد ابن يهيى الطرسوسي أبو محمد المعروف بالضعيف لأنه كان كثير العبادة وقيل نحيفا وقيل لشدة إتقانه ثقة من العاشرة. ، تقريب التهذيب المؤلف: أبو الفضل أحمد بن علي بن محمد بن أحمد بن حجر العسقلاني (المتوفن: 852هـ)، المحقق:

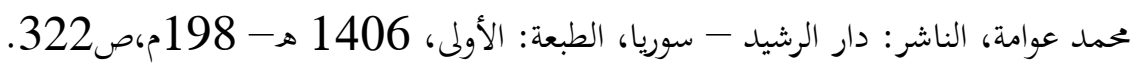

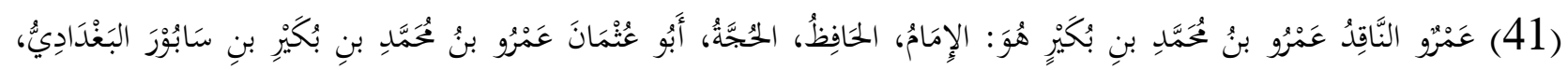

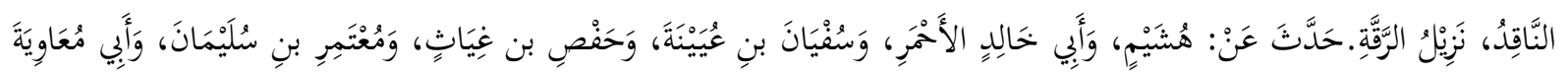

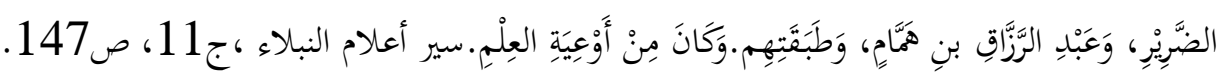

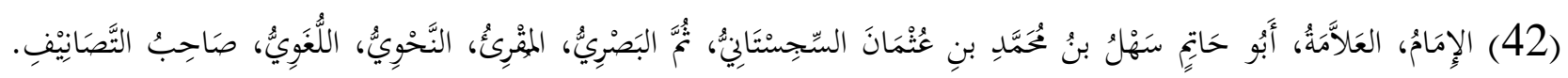

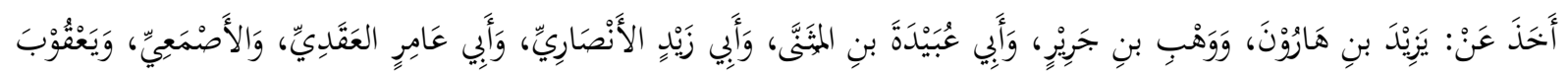

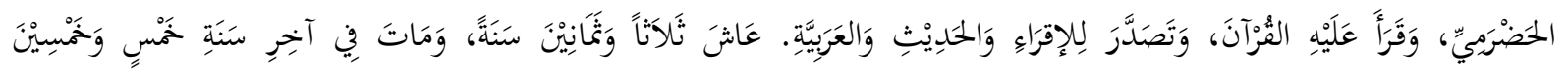

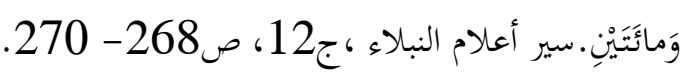


لم أجد له ترجمة.

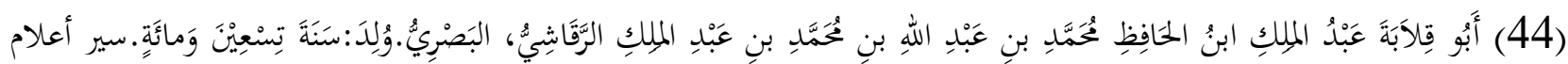

$$
\text { النبلاء ، ج13، ص14. }
$$

(45) معرفة القراء الكبار على الطبقات والأعصار ، لشمس الدين أبو عبد الله محمد بن أحمد بن عثمان بن قَايمْاز الذهبي (المتوفى:

$$
\text { 748هـ)، الطبعة: الأولى } 1417 \text { هـ- 1997م ، الناشر: دار الكتب العلمية ، ص94. }
$$

(46) كعب بن إبراهيم، روى القراءة عن يعقوب وهو معدود في أصحابه، روى القراءة عنه الحسن بن مسلم، كذا في كامل الهذلي،

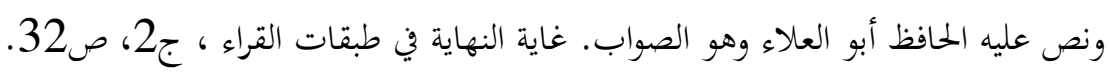

(47) مسلم بن سفيان البصري المفسر الضرير، روى القراءة عن يعقوب نفسه، هذا هو الصواب كما قطع به الحافظ الممذاين وغيره،

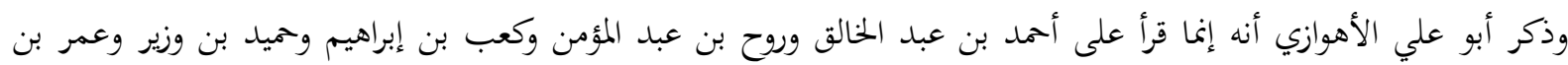
سراج أصحاب يعقوب عن يعقوب والله أعلم، روى القراءة عنه ابنه الحسن. غاية النهاية في طبقات القراء ، ج2، ص298.

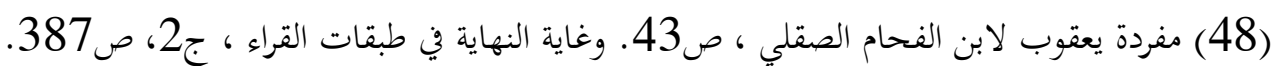

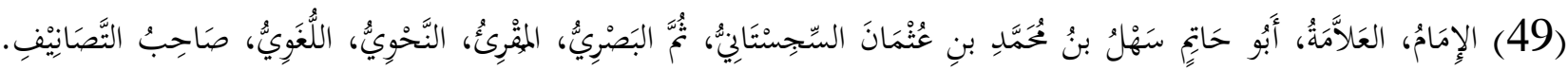

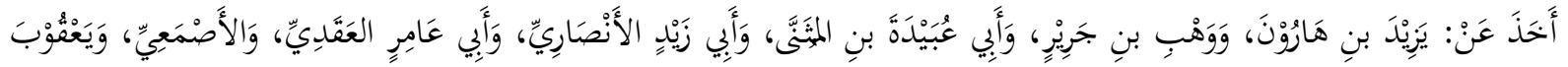

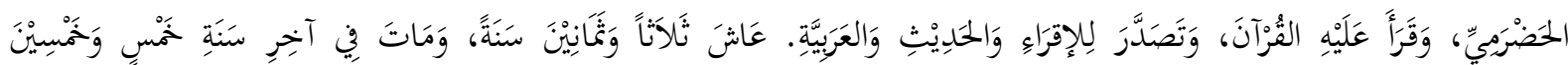

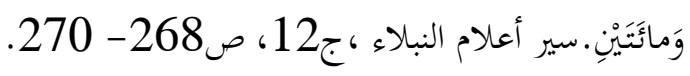

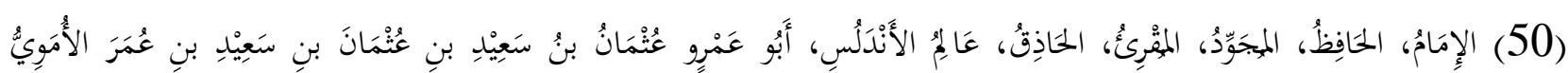

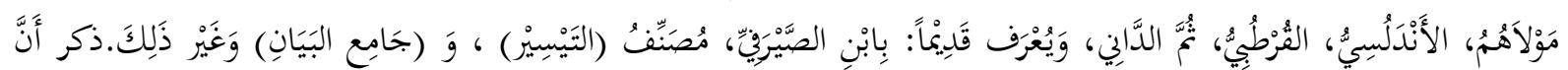

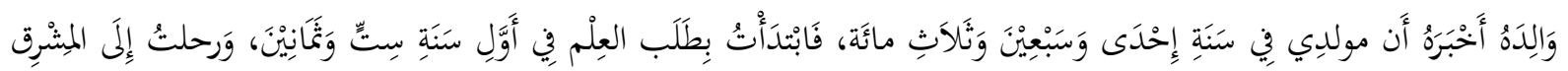

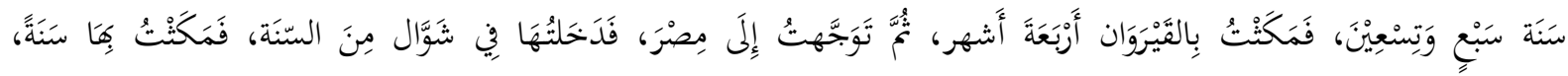

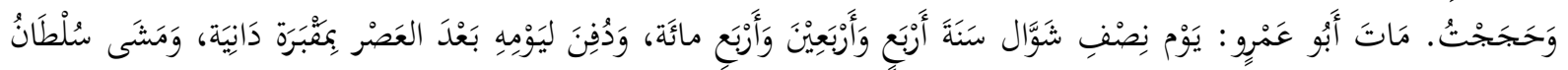

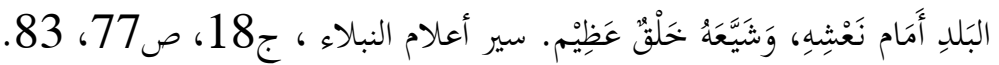
(51) طاهر بن عبد المنتم بن عبيد الله بن غلبون بن المبارك أبو الحسن الحلبي نزيل مصر. ذكره 》الذهبي《 748 هـ ضمن علماء الطبقة التاسعة من حفاظ القرآن كما ذكره 》ابن الجزري《) ت 833 هـ، ضمن علماء القراءات.نشأ 》طاهر بن غلبونه في بيت

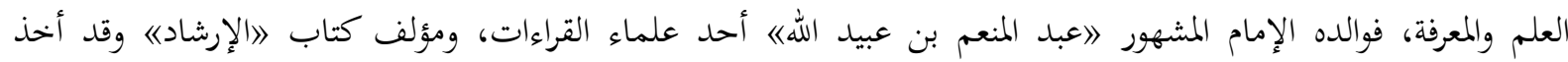
》اطاهر| القراءة وحروف القرآن، عن عدد كبير من خيرة العلماء، وفي مقدمة هؤلاء 》والده عبد المنعم اتوفي اطاهر بن غلبونه سنة تسع وتسعين وثلاثمائة. رحمه الله رحمة واسعة، وجزاه الله أفضل الجزاء. معجم حفاظ القرآن عبر التاريخ للمؤلف :محمد محمد محمد سالم محيسن (المتوفن: 1422هـ ، الناشر: دار الجيل - بيروت، الطبعة:الأولى 1412 هـ - 1992م، ج2، ص ص179. (52) علي بن جعفر بن سعيد أبو الحسن السعيدي الرازي الحذاء نزيل شيراز أستاذ معروف، قرأ على أبي بكر النقاش وأحمد بن نصر 
الشذائي والحسن بن سعيد المطوعي وأممد بن العباس بن الإمام ومحمد بن أحمد بن إبراهيم المكي، قرأ عليه محمد بن علي

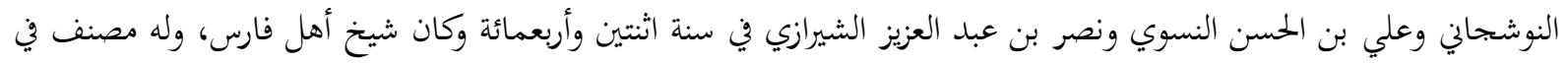

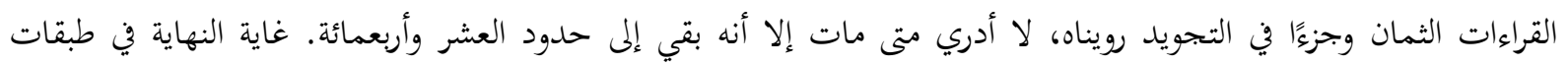

$$
\text { القراء ، ج1، ص529. }
$$

(53) عممد بن محمد بن محمد بن علي ابن يوسف أبو الخير شمس الدين العمري الدمشقي ثم الشيرازي الشافعي، المشهور بابن الجزري،

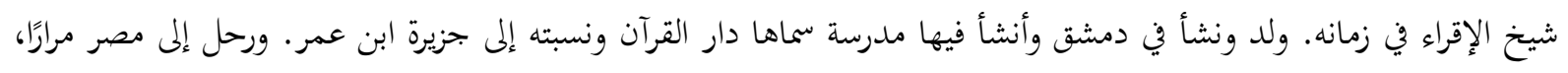

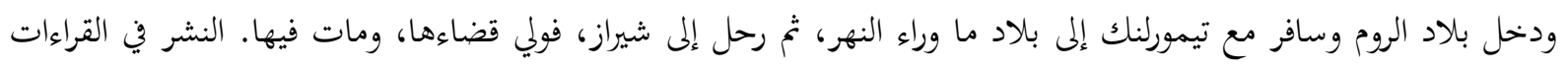

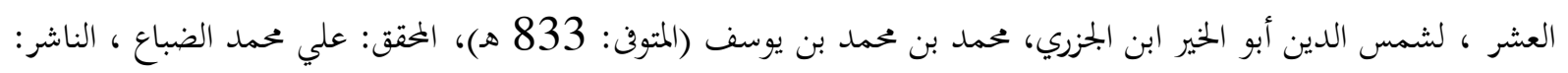

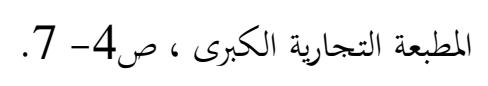

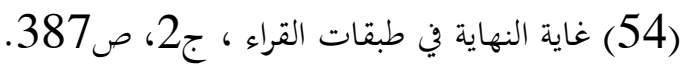

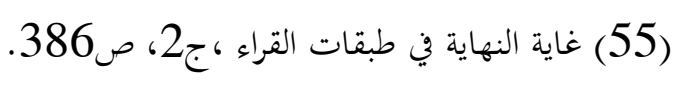

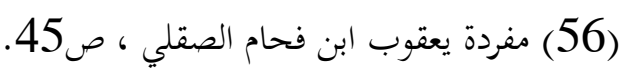

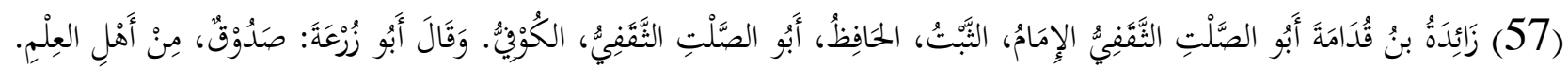

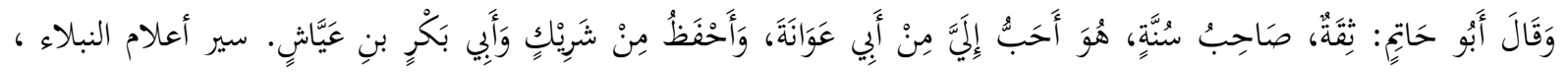

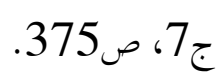

(58) مرجى بتشديد الجيم ابن رجاء اليشكري أبو رجاء البصري صدوق. تقريب التهذيب ، ج1:، ص524.

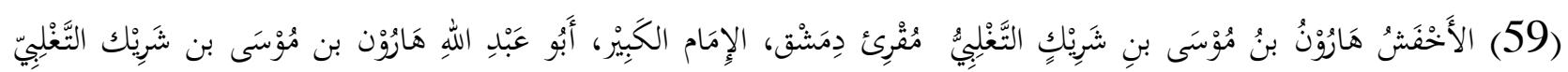

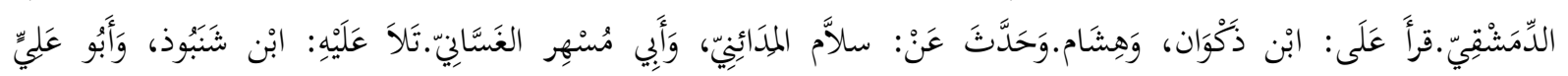

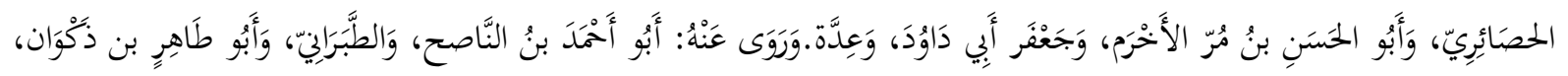

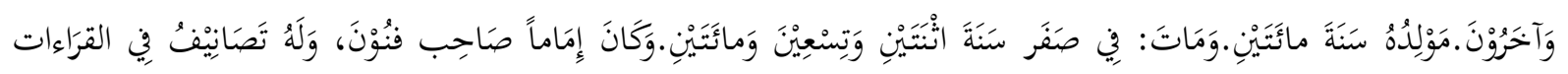

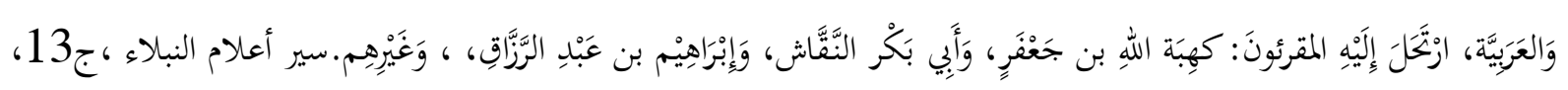

ص566.

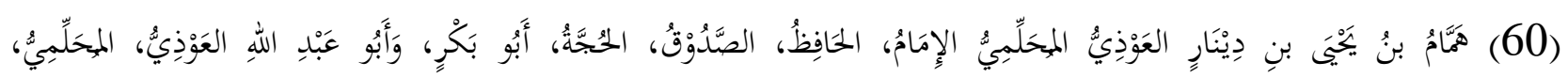

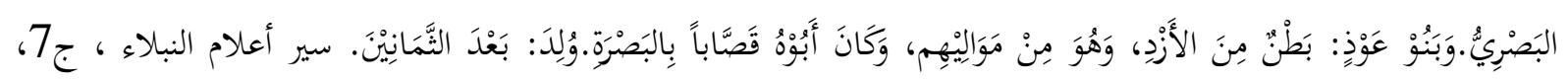

ص296.

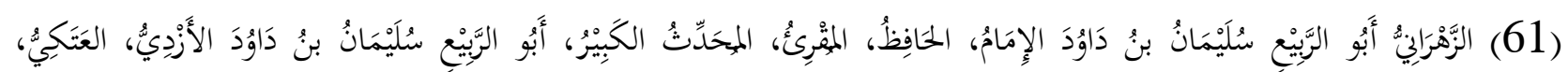

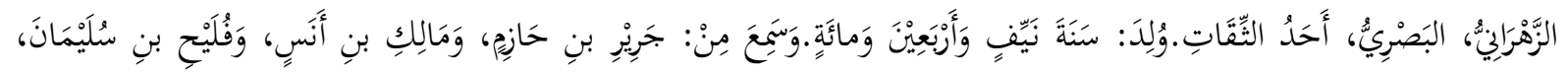

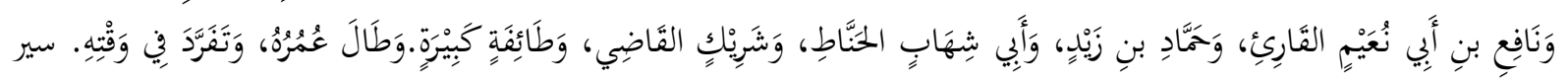

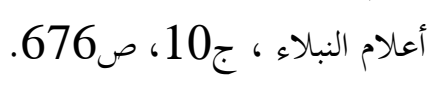




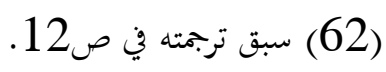

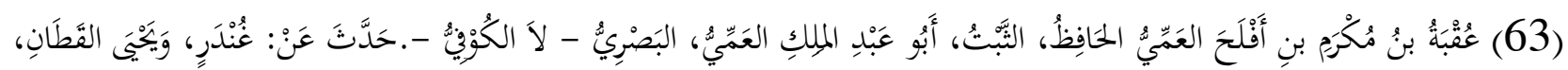

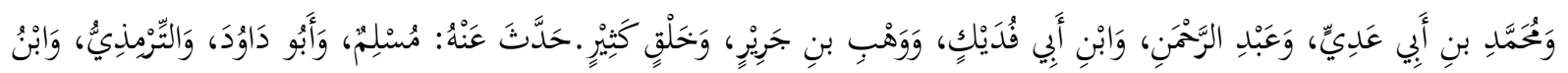

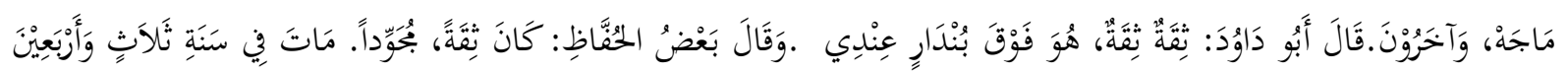

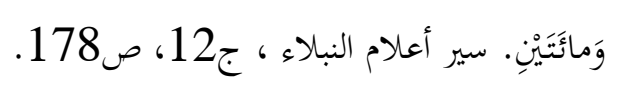

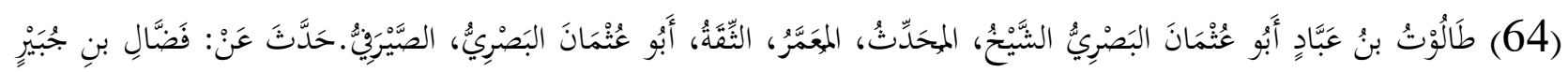

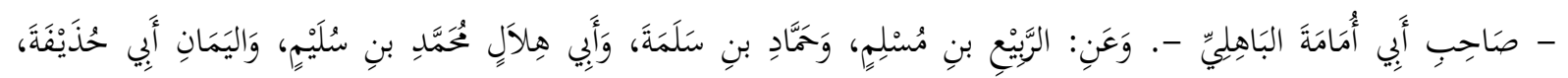

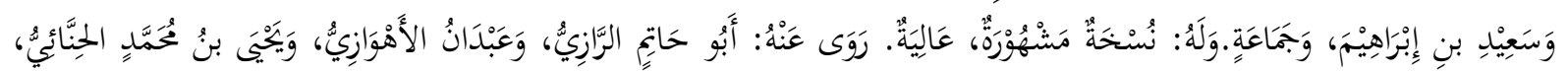

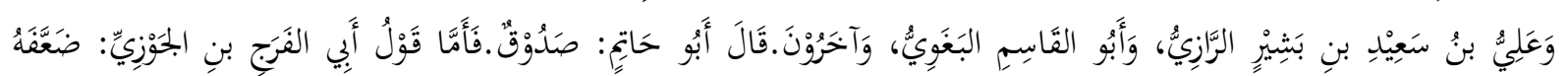

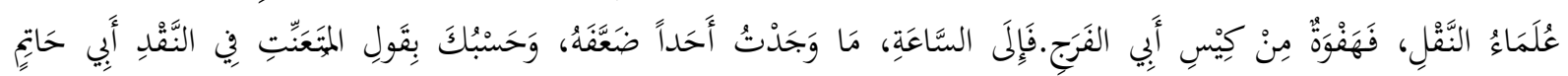

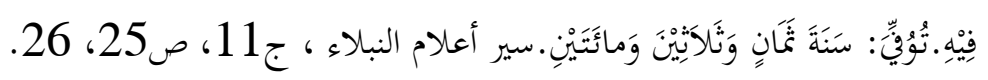

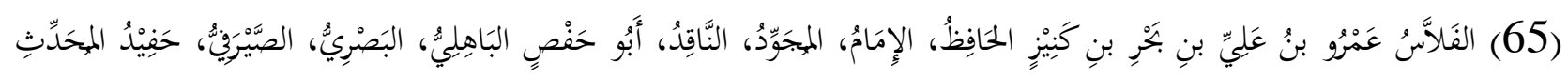

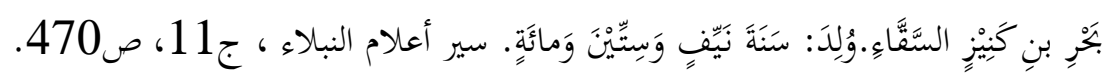

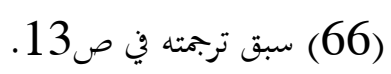

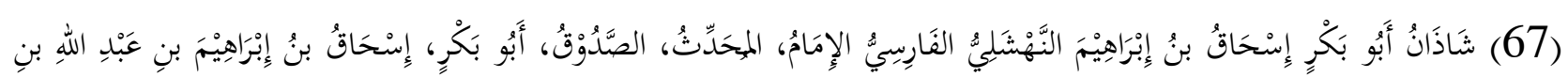

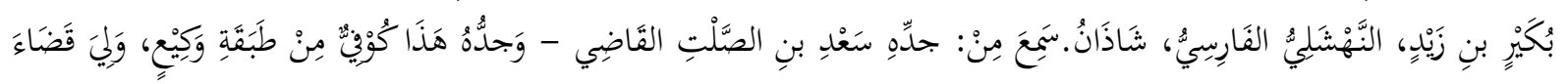

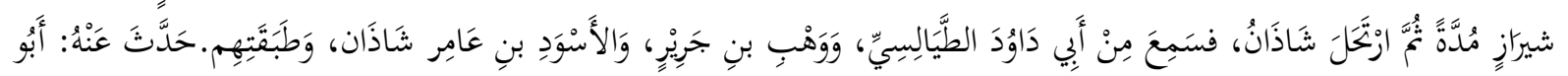

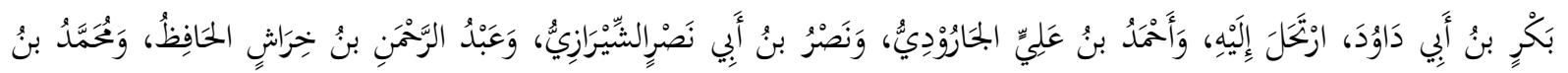

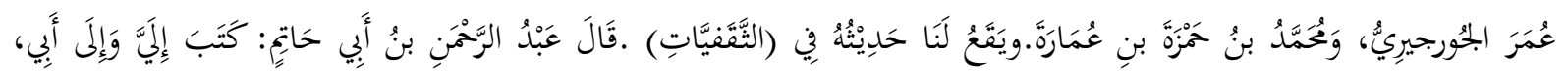

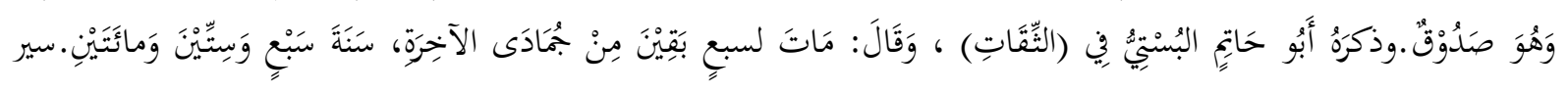

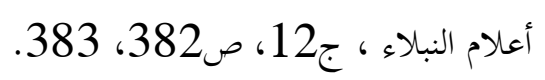

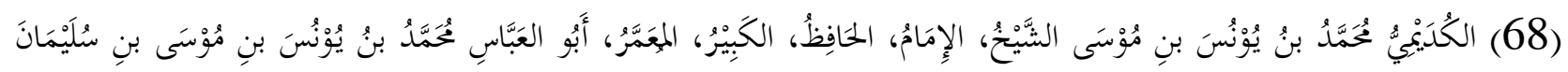

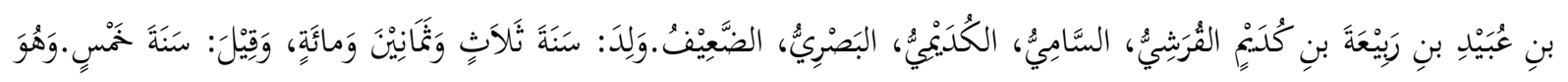

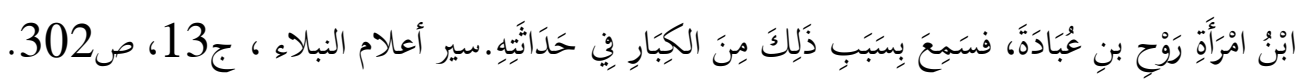

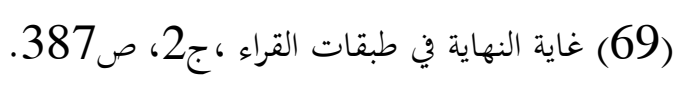

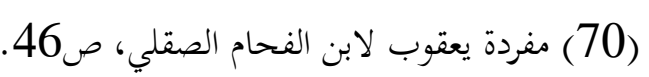

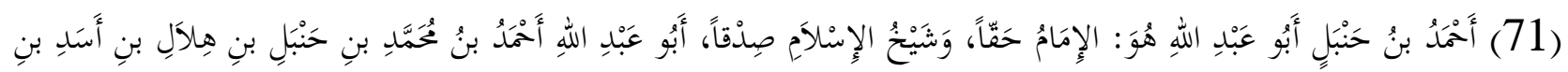

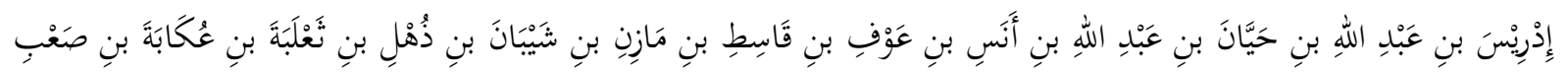

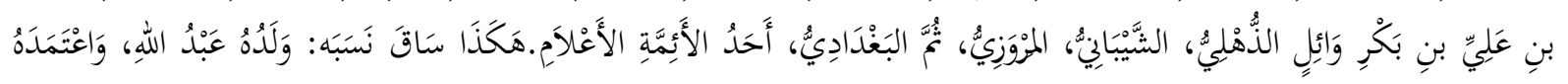




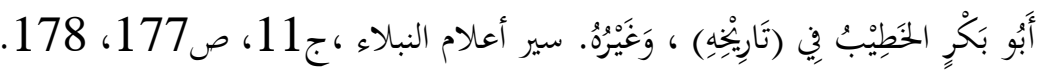

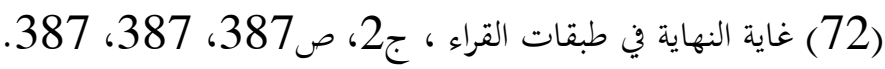

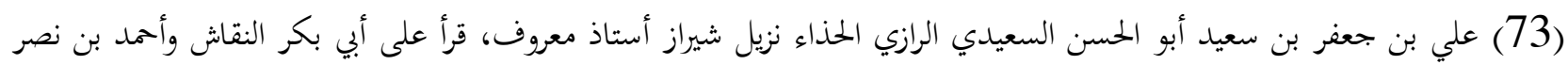

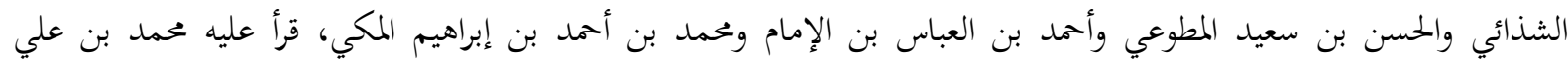

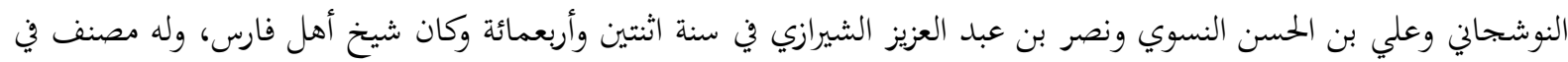

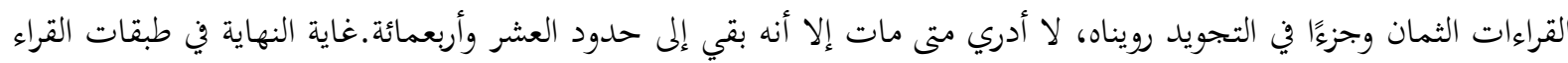

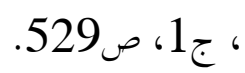

(74) غاية النهاية في طبقات القراء، ج2، ص387.

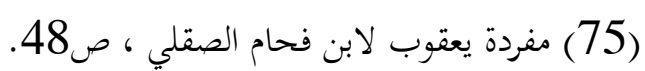
(76) (المصدر السابق: ص48)

(77) أبو القاسم الهذلي هو: يوسف بن عليّ بن جبارة بن محمد بن عقيل أبو القاسم المذلي اليشكري، الأستاذ الكبير، العالم الشهير.

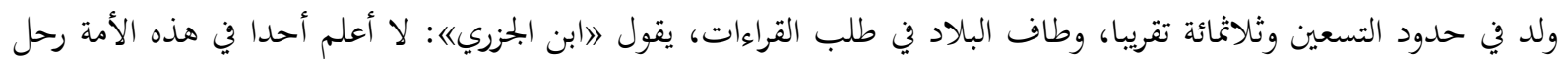

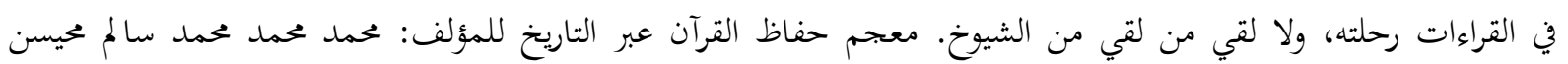

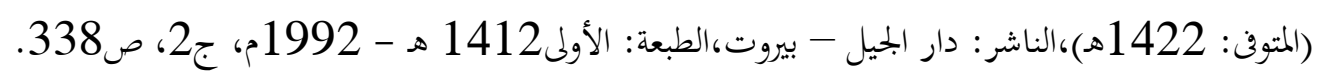

(78) مفردة يعقوب لابن فحام الصقلي ، ص49.

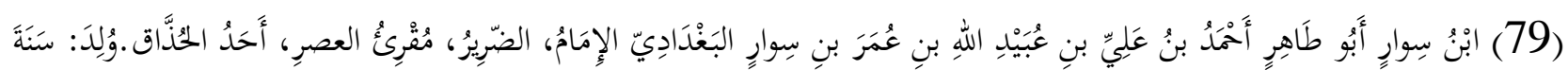

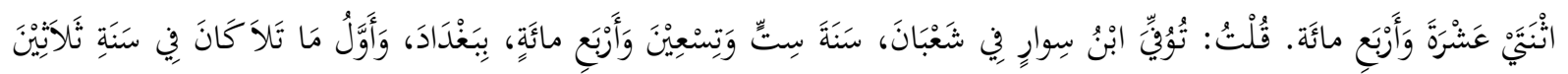

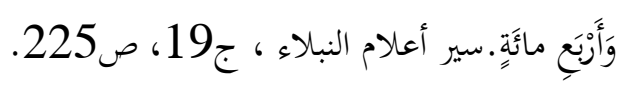$$
\text { (80) مفردة يعقوب لابن فحام الصقلي ، ص49. }
$$$$
\text { (81) مفردة يعقوب لابن فحام الصقلي ، ص49. الابن. }
$$

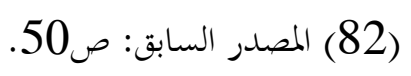

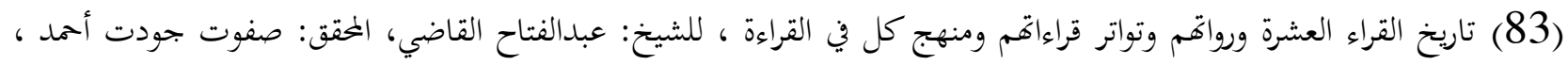
الطبعة الأولى:1419هـ - 1998م ، الناشر: مكتبة القاهرة ، ص45.

(84) معرفة القراء على الطبقات والأعصار، ص126.

$$
\text { (85) معتم حفاظ القرآن عبر التاريخ، ج1، ص248. }
$$

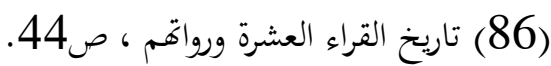

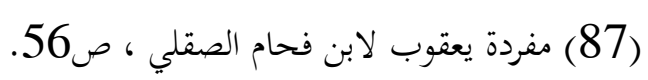$$
\text { (88) المصدر السابق: ص56. }
$$

(89) الوافي بالوفيات للمؤلف: صلاح الدين خليل بن أيبك بن عبد الله الصفدي (المتوف: 764هـ)،لخقق: أحمد الأرناؤوط وتركي 


$$
\begin{aligned}
& \text { مصطفى، الناشر: دار إحياء التراث - بيروت، ج4، ص271. } \\
& \text { (90) تاريخ القراء العشرة ورواتم ، ص44. }
\end{aligned}
$$

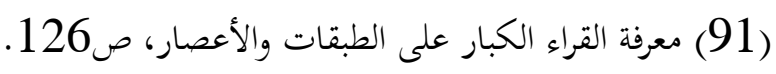

$$
\begin{aligned}
& \text { (92) معجم حفاظ القرآن عبر التاريخ ، ج1 ، ص245. }
\end{aligned}
$$

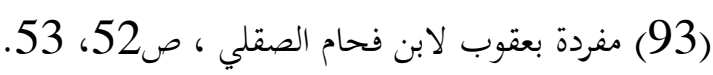

$$
\begin{aligned}
& \text { (94) مَذيب التهذيب ، ج3، ص296. } \\
& \text { (95) تقريب التهذيب ، ص211. }
\end{aligned}
$$

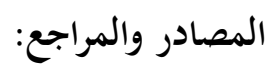

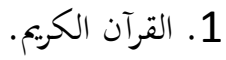

2. التاريخ الكبير للمؤلف: محمد بن إسماعيل بن إبراهيم بن المغيرة البخاري، أبو عبد الله (المتوفن: 256هـ) ، الطبعة: دائرة المعارف العثمانية، حيدر آباد - الدكن، طبع تحت مراقبة: محمد عبد المعيد خان.

3. الدرر الكامنة في أعيان المائة الثامنة لأبي الفضل أحمد بن علي بن محمد بن أحمد بن حجر العسقلاني (المتوف: 852هـ)، المحقق: مراقبة / محمد عبد المعيد ضان ، الناشر: بحلس دائرة المعارف العثمانية - حيدر اباد- الهند ، الطبعة: الثانية، 1392هـ- 1972م. 4. النشر في القراءات العشر المؤلف: شمس الدين أبو الخير ابن الجزري، محمد بن محمد بن يوسف (المتوفى: 833 هـ)، المحقق: علي محمد الضباع (المتوف 1380 هـ)، الناشر: المطبعة التجارية الكبرى.

5. تاريخ القراء العشرة ورواتم وتواتر قراءاتم ومنهج كل في القراءة ، للشيخ: عبدالفتاح القاضي، المحقق: صفوت جودت أحمد ، الطبعة الأولى:1419هـ - 1998م ، الناشر: مكتبة القاهرة.

6. تقريب التهذيب المؤلف: أبو الفضل أحمد بن علي بن محمد بن أحمد بن حجر العسقلاني (المتوف: 852ه)، المحقق: محمد عوامة، الناشر: دار الرشيد - سوريا، الطبعة: الأولى، 1406 هـ- 198م.

7. تمذيب التهذيب للمؤلف: أبو الفضل أحمد بن علي بن محمد بن أحمد بن حجر العسقلاني (المتوف: 852هـ)، الناشر: مطبعة دائرة المعارف النظامية، الهند ، الطبعة: الأولى، 1326هـ.

8. تمذيب الكمال في أسماء الرجال للمؤلف: يوسف بن عبد الرحمن بن يوسف، أبو الحجاج، جمال الدين ابن الزكي أبي محمد القضاعي الكلبي الْمِِّيّ (المتوفى: 742هـ،المحقق: د. بشار عواد معروف ، الناشر: مؤسسة الرسالة - بيروت ، الطبعة: الأولى: 1400هـ - 
9. الوافي بالوفيات للمؤلف: صلاح الدين خليل بن أيبك بن عبد الله الصفدي (المتوف: 764هـ)،الحقق: أحمد الأرناؤوط وتركي مصطفى، الناشر: دار إحياء التراث - بيروت.

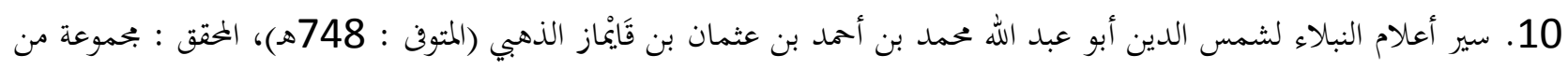

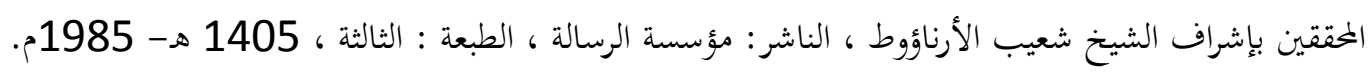

11. غاية النهاية في طبقات القراء لشمس الدين أبو الخير ابن الجزري، محمد بن محمد بن يوسف (المتوف: 833هـ)، الناشر: مكتبة

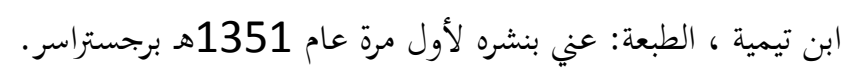

12. معرفة القراء الكبار على الطبقات والأعصار لشمس الدين أبو عبد الله محمد بن أحمد بن عثمان بن قَاِيماز الذهبي (المتوفى:

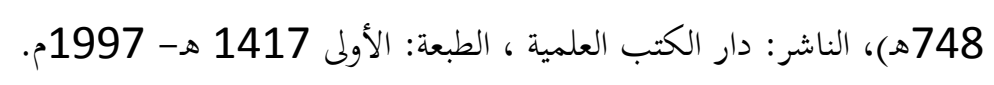

13. معجم حفاظ القرآن عبر التاريخ للمؤلف :حمد محمد محمد سالم ححيسن (المتوف: 1422هـ ، الناشر: دار الجيل - بيروت،

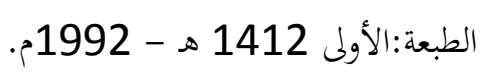

14. مفردة يعقوب للعلامة: عبدالرمن بن أبي بكر عتيق بن خلف المعروف بابن الفحام الصقلي المتوف:(516هـ) ، الطبعة: الأولى1428هـ - 2007م ، الناشر: دار أضواء السلف. 